\section{NOVA TELLVS}

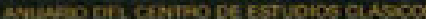

-

res
Nova Tellus

ISSN: 0185-3058

novatelu@servidor.unam.mx

Centro de Estudios Clásicos

México

Araiza, Jesús

Una aproximación a las nociones de sujeto y de verdad práctica en Aristóteles

Nova Tellus, vol. 27, núm. 1, 2009, pp. 141-189

Centro de Estudios Clásicos

Distrito Federal, México

Disponible en: http://www.redalyc.org/articulo.oa?id=59115499005

- Cómo citar el artículo

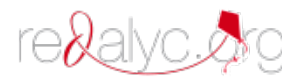

- Número completo

- Más información del artículo

Página de la revista en redalyc.org

Sistema de Información Científica

Red de Revistas Científicas de América Latina, el Caribe, España y Portugal

Proyecto académico sin fines de lucro, desarrollado bajo la iniciativa de acceso abierto 


\title{
Una aproximación a las nociones de sujeto y de verdad práctica en Aristóteles
}

\author{
Jesús AraizA \\ Universidad Nacional Autónoma de México \\ araimar_jes@yahoo.com.mx
}

RESUMEN: La verdad práctica, según Aristóteles, se da en el hombre gracias a que surge dentro del alma una opinión verdadera y simultáneamente una acción recta. Lo falso en la esfera de las acciones se produce, por el contrario, con el surgimiento de una opinión falsa y una acción no recta. El papel de la phantasía en ello es determinante, pues ésta es un movimiento que se produce a partir de la percepción en acto y el ser vivo se engaña, si confunde las imágenes con el objeto real. La causa del engaño es la imaginación, pues son las imágenes residuales que quedan después de que el objeto sensible ya no está, las que ponen en movimiento a los demás animales que carecen de intelecto, y son las que mueven al hombre en forma de sueño durante el reposo, o en forma de pasión o enfermedad durante la vigilia, a causa de que se le nubla el intelecto.

$$
* * *
$$

ABSTRACT: According to Aristotle, practical truth occurs in man due to a true opinion emerging from the soul, simultaneously with an honest deed. In contrast, the untrue in the sphere of actions occurs as a result of a false opinion and a dishonest deed. The imagination (phantasia) plays a determining role in the sphere of actions, for it is a movement produced from perception in act. The living deceive themselves if they confuse images with real objects.

The cause of illusions is the imagination, for it is the residual images remaining when the sensible object is no longer there that move other animals lacking intellect; they are also what moves man in the form of dreams during sleep or, in the form of passion or sickness during waking hours, as a result of the intellect becoming clouded over.

PALABRAS ClAVE: engaño, imaginación, percepción, sujeto, verdad práctica. KEYWORDS: illusion, imagination, perception, practical truth, subject.

RECEPCIÓN: 23 de enero de 2009.

ACEPTACIÓN: 30 de abril de 2009. 


\title{
Una aproximación a las nociones de sujeto y de verdad práctica en Aristóteles*
}

\author{
Jesús ARAIZA
}

Naturalmente hubiera sido conveniente que al mismo tiempo ellos [sc. nuestros predecesores] hablaran también acerca del engañarse, pues es más propio de los animales, y durante un tiempo más largo el alma permanece en ello [antes que en la verdad]. ${ }^{1}$

La complejidad que entrañan los conceptos de sujeto y de verdad en Aristóteles obliga a reconocer los límites que le impone la naturaleza misma de la cosa. Dado que la dificultad de una investigación como ésta es doble, quizá para quien investiga resulta necesario partir del principio de que la causa de la dificultad no está en el objeto externo sino en nosotros. ${ }^{2}$ Según Aristóteles, cuanto más simples y manifiestas son las cosas que se investigan, tanto mayor es el obstáculo que enfrenta en su contemplación el intelecto. Pues, metafóricamente, tal como se ven afectados los ojos de los murciélagos frente a la luz del sol, así padece el intelecto del alma frente a las cosas por naturaleza más evidentes (phanerôtata) de todas. ${ }^{3}$

\footnotetext{
* Este ensayo forma parte del Proyecto de Investigación "La teoría del conocimiento según la filosofía de Aristóteles" (Programa de Maestría y Doctorado en Filosofía de la FFyL-UNAM).

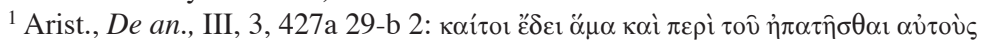

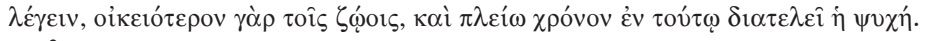

${ }^{2}$ De la causa interna de la dificultad nos advierte el mismo Aristóteles en Met., A, 1, 993b 7-9: "Pero también, siendo la dificultad de dos maneras, quizá la causa

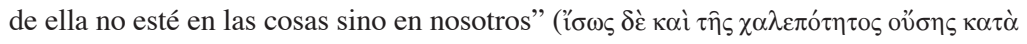

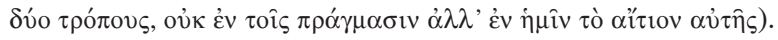

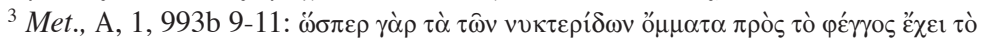

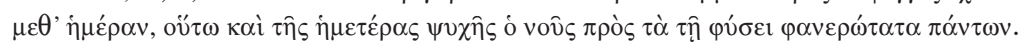




\section{Una investigación completa sobre el sujeto 4 y la verdad en Aristóteles nos llevaría, sin duda, a profundizar en el estudio}

\footnotetext{
${ }^{4}$ La palabra sujeto en Aristóteles tiene una significación más amplia que la que habitualmente se entiende hoy en día. Aquí nos referiremos al animal humano, al hombre, muy especialmente a un humano en concreto, como aquello a lo que Aristóteles denomina sujeto y sustancia. El concepto de sujeto en griego, tò hypokeímenon, quiere decir, literalmente, lo subyacente, aquello que subyace. Desde el punto de vista lógico, el sujeto (tò hypokeímenon) es aquello de lo que se predica todo lo demás y que no se predica de un sujeto [Phys., I, 6, 189a 30-

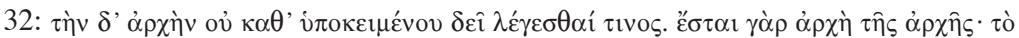

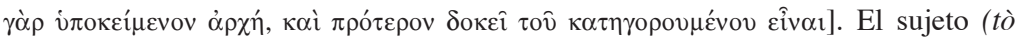
hypokeímenon) es, por tanto, en un sentido, idéntico a la sustancia (ousía). Pues la sustancia se predica de varias maneras: "Se dice la sustancia, si no en varios sentidos, sí por lo menos en cuatro especialmente: En efecto, sustancia de cada cosa parece ser el 'qué era ser', el universal, el género, y el cuarto de ellos el suje-

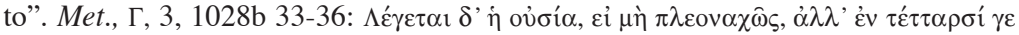

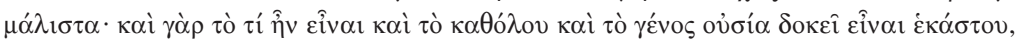

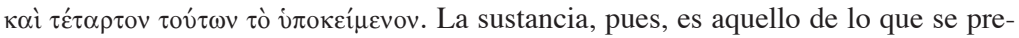
dica todo lo demás y que no se predica de un sujeto. Met., Г, 3, 1028b 36-1029a 3: "El sujeto es aquello de lo que se predica lo demás, pero él mismo ya no se predica de otra cosa. Por eso hay que discernir en primer lugar acerca de él. Pues

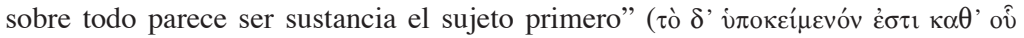

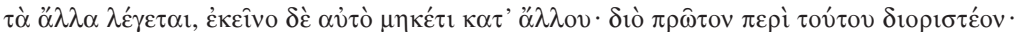

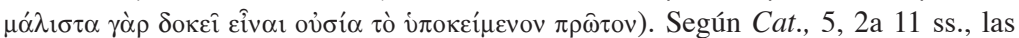
categorías o predicamentos son diez: la sustancia como aquella que se predica

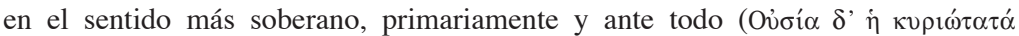

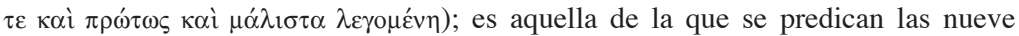
restantes: la cantidad, la cualidad, la relación, el lugar, el tiempo, la posición, la

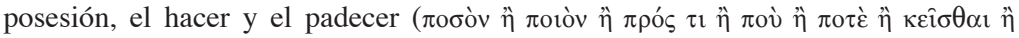

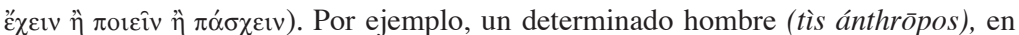
tanto que sustancia, no se predica de ningún sujeto; pues él mismo subyace (hypokeîtai) a los demás predicamentos; ese determinado hombre es un sujeto del cual primariamente (prôtôs) se predica lo demás; a saber, que es humano o animal racional (deútera ousía), que es médico (tò poîon), que mide $1.70 \mathrm{~m}$ de estatura (tò póson), que es maestro (tò prós ti), que está en la Academia (pô̂), ahora (póte), que está de pie o sentado (kê̂sthai), que opera o cauteriza (poieîn), que es operado o cauterizado (páschein), o que posee la ciencia médica (échein). Desde el punto de vista ontológico, el subjectum (tò hypokeímenon) es aquello que sub-yace (ho hypo-keîtai) o que permanece (ho ménei); es aquello que, aun cuando admite en él cambios de un contrario a otro, él mismo permanece siendo lo que es. Por ejemplo, si un determinado hombre (tis ánthrōpos, en el sentido de humano) adquiere el conocimiento médico, de una condición cualitativa de privación pasa a una condición de posesión. Pues de no ser médico llega a ser médico; o bien si de caliente llega a ser frío o de frío llega a ser caliente; pese al cambio cualitativo permanece
} 
de sus tratados de filosofía primera (metafísica), de física y de lógica. No obstante, puesto que debemos comenzar por aquello que nos es más conocido y es más accesible a nuestros sentidos, dejando para otro momento la contemplación de la cosa desde el punto de vista lógico, ontológico y epistemológico, debemos contentarnos con explorar en ensayo algunas de las vetas más accesibles que, en relación con el tema sujeto y verdad práctica, parecen ofrecernos especialmente los tratados de Ética nicomaquea, Del alma y Del movimiento de los animales. $^{5}$

siendo humano. Aunque se da, en efecto, un cambio en él, ese hombre determinado en el que se da el cambio permanece siendo ánthrōpos, es decir, un ser humano. Lo mismo sucede con el cambio cuantitativo y con el cambio de lugar: desde el nacimiento, por ejemplo, el hombre crece constantemente o se mueve de un lugar a otro; no obstante, su naturaleza subyacente (physis hypokeimênē) permanece. Desde su infancia - pasando por su adolescencia - llega a la edad adulta sin que su naturaleza subyacente cambie. Tal como ha sido dicho, el concepto de sujeto (hypokeímenon) en Aristóteles tiene la misma significación que el concepto de sustancia (ousía), de modo que si un sujeto es aquello de lo que se predica lo demás sin que él se predique de nada, será sujeto o sustancia un determinado hombre de igual manera en que un determinado caballo o una determinada planta son sujeto o sustancia. Hemos de advertir que, pese a esta extensión del concepto de sujeto en Aristóteles, prevalece como ejemplo primario el caso de un ser humano en particular (tìs ánthrōpos).

${ }^{5}$ Son tres fundamentalmente los temas que nos facilitan una aproximación al estudio de la verdad práctica en Aristóteles: (a) su teoría acerca de la acción; (b) el análisis del alma humana, la cual se divide en partes; y (c) su teoría acerca de la causa del movimiento en el animal humano. Como veremos, tanto su teoría acerca de la acción (a) como su teoría acerca del movimiento en el animal humano (c) se despliegan mediante el análisis de las partes del alma (psychê) y de su funcionamiento (b). Es decir, la acción y la causa del movimiento en el hombre se explican como fenómenos de naturaleza eminentemente psíquica. Hemos de analizar el alma en Aristóteles (cf. De an., III, 9) como un compuesto que se divide ya sea en dos partes - la racional y la irracional-, ya sea en tres especies de apetito - el anhelo, la furia y el deseo-, o también, en un sentido, en tres, pero en otro sentido, en cuatro diferentes facultades - la facultad nutritiva (tò thrēptikón), la sensitiva (tò aisthētikón) y la imaginativa (tò phantastikón), la cual, a su vez, se divide en imaginación sensitiva (aisthētikê phantasía) y en imaginación deliberativa o calculadora (bouleutikê phantasía) - . La facultad imaginativa, en efecto, se encuentra no solamente dentro del registro de lo irracional; pues, como veremos más adelante, sin phantasía no hay intelecto. De an., III, 11, 434a 7; III, 10, 433b 29: 
La verdad (alêtheia) supone concordancia entre dos dimensiones, la del pensamiento (diánoia) y la de la cosa o del hecho (tò prâgma). La falsedad implica lo contrario; ocurre cuando no hay concordancia entre lo dicho y el hecho, porque al hablante le pasa inadvertido (lanthánei) esto último y se engaña con respecto al objeto verdadero. Es verdadero opinar que lo que es es y que lo que no es no es, porque hay concordancia entre el pensamiento y la cosa; en cambio, es falso opinar que lo que es no es o que lo que no es es, porque no hay concordancia entre el pensamiento y el hecho. En efecto, si algo existe es verdadero afirmar que existe y falso negar que existe; y si algo no existe, es falso afirmar que existe y verdadero negar que existe. ${ }^{6}$ De manera que la afirmación y la negación acerca de lo mismo son necesariamente contrarias, y no es posible ni que lo mismo exista y no exista al mismo tiempo, ni que la afirmación y la negación contrarias acerca de lo mismo sean simultáneamente verdaderas o simultáneamente falsas. ${ }^{7}$ Por ejemplo, si afirmo que Calias está sentado cuando Calias está sentado, mi afirmación es verdadera; en cambio, si afirmo que Calias está sentado cuando Calias se ha puesto de pie, mi afirmación es ahora falsa ${ }^{8}$ si niego que Calias está sentado cuando Calias está sentado, la negación es falsa; y si niego que Calias está sentado cuando Calias no está sentado, la negación es verdadera. Por lo tanto, así como es imposible que Calias esté al mismo tiempo sentado y no sen-

"Toda imaginación es o bien racional o bien sensitiva. Así pues, de esta <última>

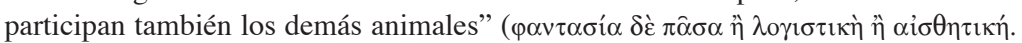

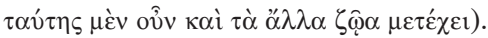

${ }^{6}$ De int., 6, 17a 26-29: "Puesto que es posible declarar lo existente como no existente y lo no existente como existente, y lo existente como existente y lo

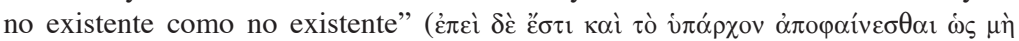

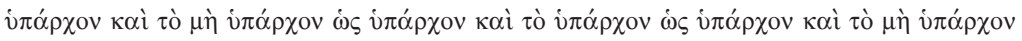

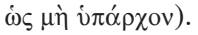

${ }^{7}$ Cf. Met., Г, 6, 1011 b 15 ss., 7, 1011b 26; Cat., V, 4a 26, 36.

${ }^{8}$ De an., III, 3, 428b 8: "sino que <una opinión verdadera> se convirtió en falsa

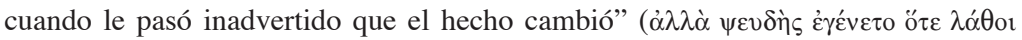
$\mu \varepsilon \tau \alpha \pi \varepsilon \sigma o ̀ v ~ \tau o ̀ ~ \pi \rho \hat{\alpha} \gamma \mu \alpha)$. 
tado, así también es imposible que la afirmación y la negación acerca de lo mismo sean al mismo tiempo verdaderas o simultáneamente falsas.

Al proceder en la determinación de lo verdadero y lo falso, Aristóteles discierne ${ }^{9}$ tres planos dentro de su teoría lógica y psicológica: la esfera del lenguaje y de la escritura, por un lado, la esfera del pensamiento, por otro, $y$, en tercer lugar, la esfera de lo que de hecho se da en el registro de lo sensible y de lo inteligible. Los signos que se dan en la voz (en têi phonêi $)^{10}$ son símbolos (sýmbola) de los signos que se dan dentro del alma (en têi psychêi) y los signos que se dan en la escritura (tà graphómena) son símbolos (sýmbola) de los que se dan en la voz. ${ }^{11} \mathrm{Y}$ así como los signos escritos no son los mismos para todos los hombres, así tampoco las voces son las mismas para todos. En cambio, las afecciones del alma, de las que primariamente las voces son símbolo, son las mismas para todos los hombres; y aquellas cosas <externas> de las que estas afecciones del alma son semejanzas, son también ya las mismas para todos. Dentro del alma hay, por tanto, conceptos (noêmata) -los objetos que el intelecto (nô̂s) intelige (noêे), a los que Aristóteles llama también afecciones (pathêmata) - de los cuales la voz es sýmbolon. La verdad o falsedad no se produce cuando no se da ni en el pensamiento ni, por consiguiente, en la

\footnotetext{
${ }^{9}$ Cf. De int., 1, 16a 1-18, 14, 23a 27-24b 9.

${ }^{10}$ Cómo define Aristóteles la voz (phonê), puede verse en De an., II, 8, 420b 27-33: "De manera que es voz el golpe del aire inspirado - por efecto del alma que está en estas partes - contra la llamada tráquea (pues no todo sonido de un animal es voz, como hemos dicho - porque es posible también hacer sonidos con la lengua, como los que tosen - sino que es necesario que un ser animado sea el que produce el golpe sonoro y que <el golpe > se acompañe de cierta imaginación,

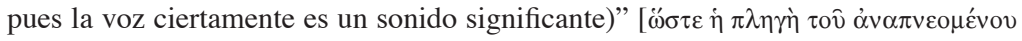

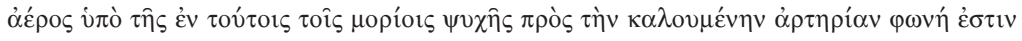

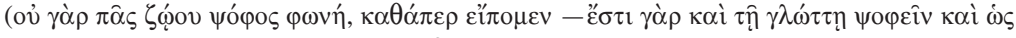

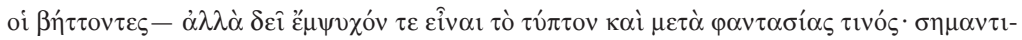

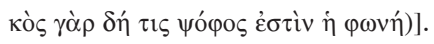

${ }^{11}$ Cf. De int., 1, 17b 7 ss.
} 
voz un concepto sin enlace. "Pues lo verdadero y lo falso consisten en un enlace de conceptos". ${ }^{12}$ Por ejemplo, los conceptos aislados "hombre" (ánthrōpos) o "bueno" (agathós) o este (hoútos) o "ser" (eînai), no son ni verdaderos ni falsos, si bien quieren decir algo. ${ }^{13}$ La verdad o falsedad se da con el enlace de conceptos, cuando al concepto se añade algo. Por ejemplo, la afirmación este hombre es bueno se compone ya de un enlace de conceptos. Dado que se habla de un hombre concreto, si el hombre del que se habla es Sócrates, la afirmación Sócrates es bueno es necesariamente o verdadera o falsa. Si la afirmación Sócrates es bueno es verdadera, la negación Sócrates no es bueno es falsa; y si la negación Sócrates no es bueno es verdadera, la afirmación Sócrates es bueno es falsa. ${ }^{14}$ Ahora bien, el que aquello que se dice sea verdadero no es causa de que el hecho exista, sino al contrario: en cierta manera el hecho se manifiesta como causa de que el enunciado (ho lógos) sea verdadero; pues el enunciado se dice verdadero o falso porque el hecho (tò prâgma) existe o no existe. ${ }^{15}$ Esto explica el papel fundamental que, en relación con la verdad o falsedad del objeto, desempeña en primer lugar la percepción sensorial (aísthèsis), y luego la imaginación (phantasía), los apetitos (oréxeis) y el intelecto (noûs). ${ }^{16}$

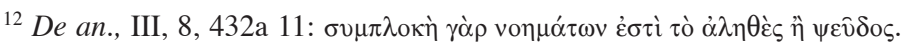

${ }^{13}$ eàn prostethêi $<t i>$ De int., 1, 16a 18.

${ }^{14}$ Met., Г, 7, 1012a 3-6: "Además todo lo pensable o inteligible o lo afirma o lo niega el pensamiento $-\mathrm{y}$ esto es evidente a partir de la definición - cuando asevera con verdad o falsedad; cuando compone de este modo afirmando o negando,

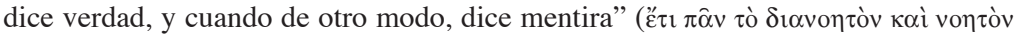

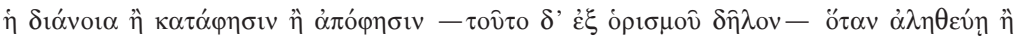

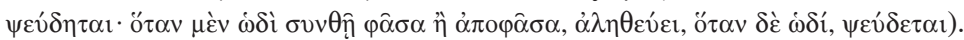

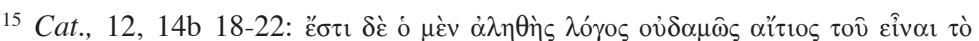

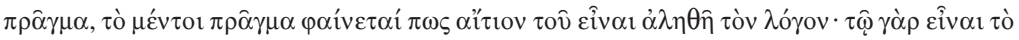

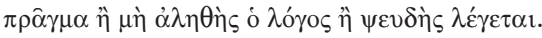

16 También la percepción sensorial es para el animal el principio del conocimiento y del saber, de las artes, de la experiencia y de la memoria. En efecto, sin percepción sensorial (aísthēsis) no hay posibilidad de aprendizaje ni de conoci-
} 
Hemos dicho, con Aristóteles, que la verdad o falsedad no se produce cuando no se da ni en el pensamiento ni en la voz un concepto sin enlace. Por ejemplo, ni la imagen conceptual hombre ni la voz hombre es verdadera o falsa, si no se le añade es o no es <algo >; porque lo verdadero y lo falso como está dicho consisten en un enlace de conceptos. ${ }^{17}$ Pues bien, el percibir sensorialmente es semejante al concepto sin enlace y a la voz sin enlace. ${ }^{18}$ Percibir una antorcha es semejante a aquella imagen que se da en el pensamiento, imagen de la cual la voz antorcha es símbolo. El percibir el objeto sensible concreto no parece indicar todavía verdad o falsedad, como tampoco hay aún verdad o falsedad en la simple imagen conceptual antorcha ni en la sola voz significativa antorcha. En cambio, si, al percibir que la antorcha es fuego, el que ve, reconoce - por ver que se mueve- que es el enemigo, entonces ya la percepción podría llegar a ser o verdadera o falsa.

Los sentidos (aisthêseis) contribuyen primariamente en el animal al discernimiento de los objetos sensibles; de hecho

miento particular o universal. Pues las ciencias y las artes son en cierto modo resultado de la experiencia y de la formación de principios universales en el animal, y tanto los principios como la experiencia resultan de un proceso de aprendizaje en el que la memoria desempeña un papel fundamental. No hay memoria sin percepción sensorial. La memoria se da en el animal cuando éste, además de recibir en él los objetos sensibles, es capaz de retener dentro de él la imagen del objeto sensible. Por eso afirma el Estagirita que aquellos animales que son capaces de recordar son más prudentes y más capaces de aprender que los que no pueden recordar. Aprenden - dice - cuantos, además de la memoria, poseen el sentido del oído. En cambio el resto de los animales que no pueden oír viven con sus fantasías (taîs phantasíais) y sus recuerdos (kaì taîs mnêmais) y participan poco de la experiencia (Met., A, 1, 980a 29 ss. Cf. An. post., II, 19). Qué cosa es la prudencia según el pensamiento de Aristóteles, es un problema cuya investigación he comenzado en otro escrito (cf. J. Araiza, "La relación entre phrónēsis y sophía, entre bíos politikós y bíos theorētikós en Magna Moralia y en Ethica Nicomachea de Aristóteles", Noua tellus, 25-2, 2007, pp. 183-207).

${ }^{17} \mathrm{Cf}$. nota 12.

${ }^{18}$ De an., III, 7, 431a 8: “Así pues, el percibir es semejante al simple declarar

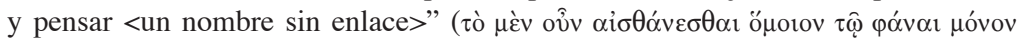

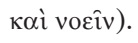


ellos constituyen la facultad del alma que en más alto grado contribuye al conocimiento de los objetos singulares. ${ }^{19}$ Sin embargo, los objetos sensibles (tà aisthêtá) son de tres especies y lo verdadero no se da sino solamente en los primeros. En efecto, respecto de la primera clase de objetos la sensación no se engaña; ${ }^{20}$ en cambio, en relación con las otras dos especies de objetos sensibles, la sensación incurre en engaño. Los primeros son los objetos propios (tà ídia) de cada sentido: el objeto propio de la vista es el color, el del oído el sonido, el del gusto el sabor y el del olfato el olor. La peculiaridad de éstos radica en que cada uno es percibido por un solo sentido y por ningún otro y en que la sensación no se engaña acerca del objeto. El color, en efecto, sólo puede ser percibido por la vista, el sonido sólo puede ser percibido por el oído, el sabor por el gusto y el olor por el olfato; y la vista no se engaña (ouk apatâtai) al percibir el color, por ejemplo, que es blanco, ni el oído al percibir el sonido, por ejemplo, que es agudo, ni el gusto al percibir que el sabor es dulce. ${ }^{21}$ Los segundos son los objetos sensibles por accidente (tà symbebēkóta); son aque-

${ }^{19}$ Met., A, 1, 981b 11: “<Las sensaciones> proporcionan el conocimiento más

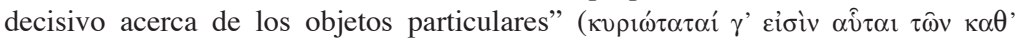

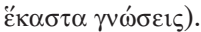

${ }^{20} \mathrm{O}$ en todo caso incurre en lo falso en muy pequeña medida. De an., III, 3, 428b 18: "La sensación de los objetos propios es verdadera o contiene sólo en

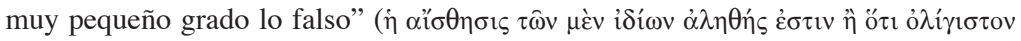

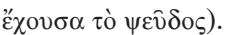

${ }^{21}$ A menos, desde luego, que se trate de una naturaleza enferma o corrompida, pues las mismas cosas no parecen dulces al que tiene fiebre y al que está sano, ni lo mismo parece caliente al débil que al que tiene una buena constitución corporal. El hombre sano y el que tiene una buena constitución corporal es, según la teoría de Aristóteles, la medida de los objetos sensibles. Desde el punto de vista de su constitución anímica, el hombre bueno en cuanto que es una especie de término medio - pues está sano- es la medida de todas las cosas (cf. EN, X, 5, 1076a 12). En cuanto a la acción, el fin se le muestra con verdad al que posee un modo de ser excelente; en cambio al que posee un modo de ser malo se le muestra como fin cualquier cosa. El que es excelente en cuanto al carácter (ho spoudaîos) juzga cada cosa correctamente, y en los objetos singulares se le muestra lo verdadero, tal como si él fuera canon y medida de ellos. Cf. EN, III, 4, 1113a 25-b 4. 
llos en los que accidentalmente se dan los objetos propios, y es en ellos en donde es posible que el sentido se engañe. Por ejemplo, la vista no se engaña en que el objeto que está percibiendo es de color blanco, pero en que ese objeto blanco es el hijo de Diares o el mismo Diares, ya es posible que mienta. La tercera clase de objetos sensibles son los llamados comunes (tà koiná). Son aquellos que no son percibidos exclusivamente por un solo sentido, sino que son comunes a todos: por ejemplo, el movimiento y el reposo, el número, la forma y la magnitud; pues percibir el movimiento o el reposo de un objeto es posible no sólo a la vista y al tacto sino también al oído. En estos últimos objetos sensibles como en los que se perciben por accidente la sensación puede incurrir ya en engaño. En la consideración de la causa y el modo en que se produce el engaño es preciso que investiguemos el papel de la phantasía o imaginación, pues la imaginación parece ser la responsable de que nos engañemos tanto con respecto a qué cosa es el objeto en el que se da el sensible propio o en dónde se encuentra, como con respecto a si está en movimiento, qué forma o magnitud tiene o si es uno, son dos o son más en número.

La sensación (aísthēsis) es la facultad mediante la cual el alma recibe dentro de sí las formas del objeto sensible sin la materia, es como la cera que recibe el sello del anillo sin el bronce y sin el oro. ${ }^{22}$ Así también cada órgano sensorial es capaz de recibir el objeto sensible sin la materia, como el ojo recibe el color sin el objeto, el oído recibe el sonido sin los objetos que chocan y lo producen en el aire, y el olfato recibe el olor sin la materia del cuerpo del que procede el olor. La percep-

\footnotetext{
${ }^{22}$ De an., II, 12, 424a 17. Otra metáfora ilustrativa sirve a Aristóteles para determinar la naturaleza del alma como receptáculo de las formas sin la materia: es la analogía del alma con la mano. Tal como la mano coge dentro de ella la piedra, así el alma recibe dentro de ella, si bien no la piedra, sí la forma: "Pues la piedra no está en el alma, sino la forma <de la piedra >, de manera que el alma es como la mano, pues también la mano es instrumento de instrumentos y el intelecto es forma de formas y la sensación forma de los objetos sensibles" (De an., III, 8, 431b 29432a 3$)$.
} 
ción se produce, por tanto, cuando - de manera semejante en que el sello del anillo toca la cera - el objeto sensible entra en contacto con el órgano sensorial. Dicho órgano posee la facultad de recibir en él la forma del objeto sin la materia de la cual éste está constituido. El ojo recibe dentro de él, sin la llama, el color propio de la llama que se da en la antorcha. Pero a este movimiento anímico por el cual dentro del órgano sensorial se signa la imagen del objeto sin la materia le siguen dos fenómenos que se originan en la misma región del alma: la memoria (mnêmē) y la imaginación (phantasía).

La memoria o el recuerdo (mnêmē) se produce en el animal de modo semejante a como tiene lugar la sensación. La diferencia entre ésta y aquélla es el tiempo, pues la una se produce en el presente, la otra en cambio una vez que transcurrió un tiempo. La percepción es del presente y tiene lugar en el presente, cuando actualmente el ojo ve, el oído oye o el gusto toca y gusta. La memoria, en cambio, es del pasado; no se produce sino una vez que ha tenido lugar la percepción de un objeto cuando ha transcurrido tiempo (hótan génētai chrónos). ${ }^{23}$ La memoria es, por tanto, la imagen de semejanza (eikôn) que queda en la misma sede de la percepción sensorial, después de que ya ocurrió la percepción de algo; pues es entonces, tras haber transcurrido tiempo, cuando el animal recuerda que vio, oyó o probó algo. La memoria es, por tanto, aquella afección que está presente cuando ya el objeto está ausente, es la permanencia (monê) de la huella que se signa en una parte del alma - como el sello que se ha grabado en la cera a través del movimiento de la percepción - y que queda dentro del animal, como una pintura (zōgráphèma), luego del contacto entre el objeto sensible y el órgano sensorial. La facultad de la percepción es, pues, en el alma, como la cera que recibe el sello del anillo sin el bronce y sin el oro, mientras la memoria es la afección (páthos) que queda dentro, es la

\footnotetext{
${ }^{23}$ Cf. De mem. et rem., 1, 449b 25.
} 
permanencia del sello del anillo sin el bronce y sin el oro, en aquella parte corporal en la que se da la sensación. ${ }^{24}$

Según Aristóteles, la imaginación (phantasía), comparte con la memoria tanto la sede en el alma como los objetos a los que se refiere, pues ambas se generan a partir de la actividad de la percepción sensorial en la misma región en donde esta última se produce, y son recordables por sí mismas aquellas cosas de las que también hay imaginación; recordables por accidente, cuantas no son sin imaginación. ${ }^{25}$ Pues bien, para decirlo en

${ }^{24}$ Cf. De mem. et rem., 1, 450a 25-32: “Uno podría plantear la aporía de cómo es que alguna vez estando presente la afección pero estando ausente la cosa se recuerde lo que no está presente. Es evidente, en efecto, que es necesario pensar una cosa tal como la que se origina a través de la sensación en el alma y en la parte corporal que posee a aquélla; así, por ejemplo, alguna pintura es la afección, aquella de la cual decimos que su posesión es memoria. En efecto, el movimiento producido se signa dentro, como cierto grabado de la cosa percibida, tal y como hacen los que sellan con sus anillos". Según la teoría del conocimiento de Aristóteles, la memoria desempeña una función fundamental en la generación de la razón (lógos), de la experiencia, del arte y la ciencia en el animal humano. Cf. An. post., II, 19, 99b 15-100b 17: "Pues <los animales> tienen una facultad innata capaz de discernir, que se llama sensación; sin embargo, aunque la sensación se da dentro, en algunos animales se engendra la permanencia (monê) de la cosa percibida, en otros no se engendra. Pues bien, aquellos en los que no se engendra - ya sea en general o en relación con las cuales no se engendra - no tienen conocimiento fuera de la percepción; en cambio en aquellos en los que sí se da tienen, después de la percepción $<$ la permanencia $>$ en el alma. Y al producirse muchas $<$ percepciones $>$ de tal clase, se produce ya una diferencia, de modo que en algunos se genera a partir de la permanencia de tales percepciones la razón (lógon), en otros, sin embargo, no se genera.

Así pues, a partir de la percepción se produce la memoria, tal como decimos, y, a partir de la memoria producida de la misma cosa muchas veces se produce la experiencia, pues muchos recuerdos en número constituyen una sola experiencia. $\mathrm{Y}$ a partir de la experiencia o de todo universal que se ha asentado en reposo en el alma - el uno junto a los muchos, lo cual en todos estos <muchos $>$ como uno es lo mismo-, es un principio del arte y de la ciencia; si se refiere a la generación, del arte, si del ser, de la ciencia. Tampoco los modos de ser entonces existen dentro ya definidos, ni se producen a partir de otros hábitos más conocidos, sino a partir de las percepciones, como en una batalla al producirse un viraje, después que se detiene uno se detiene otro y luego otro, hasta que llega al principio. El alma es fundamentalmente de tal clase, que es capaz de experimentar esto".

${ }^{25}$ Cf. De mem. et rem., 1, 450a 22-25. 
una palabra, según la teoría del Estagirita, la imaginación es la causante principal de que el hombre viva en el engaño o mienta. Veamos, así sea de manera esquemática, cómo define la phantasía y cómo explica la generación de ésta y su relación con la verdad y falsedad, con lo bueno y lo malo, con la percepción sensorial, la opinión y el intelecto.

La phantasía es el movimiento (kínēsis) que se produce por efecto de la sensación en acto, es decir, por la actividad de la sensación. ${ }^{26}$ Es imaginación (phantasía) el movimiento que se produce, primero, al percibir este color determinado - sea rojizo, amarillo o anaranjado-, luego, al percibir que aquello en lo que se da el color es la llama de una antorcha, y, finalmente, es el movimiento que, al ver que el objeto se mueve, lleva a la creencia de que se trata del enemigo. En la percepción de los tres objetos sensibles - el propio, el accidental y el común - se produce, pues, un movimiento respectivo. La percepción del color y del movimiento que se produce - de que es precisamente este color determinado el que se percibe y no otro - son verdaderos; en cambio, tanto la percepción e imaginación acerca de qué es aquello en lo que se da el color percibido, como la percepción e imaginación acerca de si eso mismo se mueve, está en reposo, es de esta magnitud o es uno, dos o más en número, pueden ser falsas, sobre todo si el objeto está lejos. ${ }^{27}$ Una afirmación de Aristóteles que a primera vista parece enigmática, pero que encierra sin duda una revelación sustancial sobre la naturaleza de la imaginación, es aquella de que "el primer movimiento que se produce en presencia de la sensación es verdadero, mientras que los otros dos pueden tanto en presencia como en ausencia de la sensa-

\footnotetext{
${ }^{26}$ Cf. De an., III, 3, 429a 1. Cf. 428b 13, 25. Cf. De insomn., 1, 459a 17.

${ }^{27}$ De an., II, 6, 418a 14-16: "Pero al menos cada <sentido> juzga acerca de estos objetos y no se engaña acerca de que es color o de que es sonido; sino acerca de qué es lo que posee el color o dónde está, o qué es lo sonoro o dónde está" ( $\dot{\alpha} \lambda \lambda$ ')

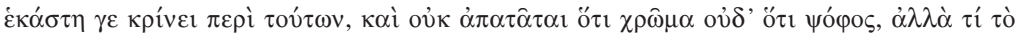

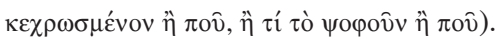


ción ser falsos, especialmente cuando el objeto sensible está lejos". ¿Qué significa tanto en presencia como en ausencia de la sensación? Es claro que, al decir en presencia de la sensación, se refiere al movimiento que desencadena el acto de la sensación; es, pues, el movimiento desencadenado por la afección del órgano sensorial al momento en que éste percibe el objeto sensible. En su escrito Acerca de los sueños ${ }^{29}$ plantea el Estagirita el problema de si percibimos el acto de soñar con la percepción o con la opinión, y si el fenómeno del sueño tiene que ver con el percibir o con el pensar. En efecto, dice, dentro del reposo (en tô̂s hýpnois), parecemos ver de modo semejante que quien se aproxima es hombre y que es blanco; y afirma que, además, a un lado de la imagen ${ }^{30}$ pensamos alguna otra cosa, de la misma forma en que durante la vigilia acerca de lo que percibimos también pensamos algo. Pues bien, este pensamiento que desencadena el acto de la percepción durante la vigilia, siendo análogo a la opinión que se produce a un lado de la imagen dentro del dormir, es obra de la imaginación. Y aun en la vigilia, en presencia de la sensación lo mismo que en ausencia de la misma, puede engañarnos:

De manera que es evidente que la imagen (phántasma) dentro del dormir no es tampoco el sueño todo y que aquello que pensamos dentro con la opinión, lo opinamos. Sin embargo, lo que sin duda en torno a todo esto es tan evidente, es que aquella misma parte con la que despiertos somos engañados durante las enfermedades, esa misma durante el dormir produce la afección (páthos). ${ }^{31}$

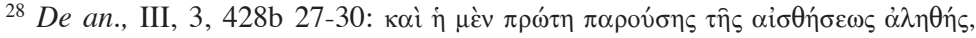

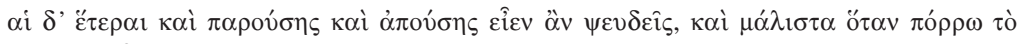
$\alpha i o \theta \eta$ òv

${ }^{29}$ Cf. De insomn., 1, 458b 15 ss.

30 "El sueño (enýpnion) es una especie de imagen (phántasma) que se produce dentro del dormir (en hýpnion)”. Cf. De insomn., 3, 462a 16.

${ }^{31}$ Cf. De insomn., 1, 458b 25.
} 
La causa del engaño durante el reposo parece ser el engaño que se produce durante la vigilia a partir de la actividad de la sensación. Y es que con el movimiento que se produce dentro del órgano sensorial cuando éste entra en contacto con el objeto sensible, ocurre lo mismo que con aquellos objetos proyectados que, aunque ya no están en contacto con lo que los puso en movimiento, se mueven. Pues aquello que los puso en movimiento, dice Aristóteles, movió cierta cantidad de aire y, ésta, al moverse, movió a su vez otra; y de este modo el motor produce el movimiento lo mismo en el aire que en el agua hasta que el objeto proyectado se detiene. ${ }^{32}$ De manera semejante, pues, a un objeto que, una vez proyectado, se sigue moviendo aunque aquello que lo puso en movimiento ha cesado de moverse, el movimiento que los objetos sensibles producen en los órganos sensoriales no sólo está presente dentro de ellos cuando las sensaciones están presentes, sino también una vez que éstas se han ido. Y las imágenes que quedan luego que ha cesado la actividad de la percepción son semejantes a las sensaciones; de modo que, por razón de que las imágenes (phantásmata) permanecen dentro del órgano sensorial como residuo o resto (hypóleimma) ${ }^{33}$ de la percepción y siguen mo-

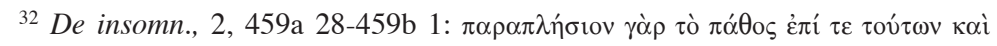

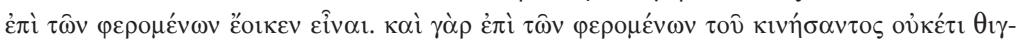

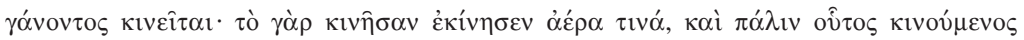

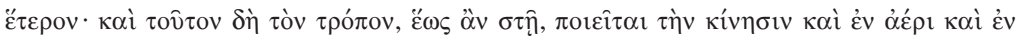
toîs ìjpoîs.

${ }^{33}$ No es objeto del presente ensayo descubrir semejanzas o nociones paralelas entre las teorías de Aristóteles y de Freud sobre la función de la phantasía y de la percepción sensorial en la génesis del fenómeno onírico y de ciertas enfermedades y afecciones que se dan durante la vigilia. Éste será objeto de una investigación posterior. No obstante, es preciso dejar aquí constancia de que, al tropezar en nuestro análisis del fenómeno de los sueños en Aristóteles con la explicación de los restos (hypóleimma) que quedan dentro - aun después de que cesa el acto de la percepción- como causantes del fenómeno onírico, es imposible que no evoquemos al punto el paralelismo que ella presenta con la explicación en Freud de los restos diurnos como generadores de las imágenes y de los pensamientos que dan forma a los sueños. Cf. De insomn., 3, 461b 21. Cf. 461a 18: hai hypóloipoi kinêseis. 
viéndose, y porque esas imágenes residuales son semejantes a las sensaciones (kai homoías eînai tâ̂s aisthêsesi), muchos animales actúan en conformidad con ellas, sea porque carecen de intelecto como las bestias, sea porque el intelecto se nubla a veces en la pasión, en la enfermedad o dentro del dormir: ${ }^{34}$

Ahora bien, cada una de estas <semejanzas $>$, como ha sido dicho, es un resto (hypóleimma) de la cosa percibida en acto. Y después de que el objeto verdadero (toû alêthoûs) que estaba presente se ha ido, también es verdadero decir (alēthés eipeîn) que es tal cual es Corisco, pero que no es Corisco. Cuando estaba en acto la percepción, la parte soberana del alma y la parte que juzga no llamaba Corisco <a la imagen $>$, sino que por causa de ésta $<i$. e. por la imagen de Corisco y por su semejanza con el objeto percibido> reconocía al Corisco verdadero (tòn aletthinón). Por tanto, aquel objeto del cual dice, cuando lo percibe, que es Corisco $<\ldots>$, tal como sucede al percibirlo, ese objeto es movido por los movimientos que tienen lugar dentro de los órganos sensoriales, y el objeto semejante (tò hómoion) parece ser el objeto verdadero (tò alēthés). La potencia del dormir es tan grande, que hace que esto se nos oculte (lanthánein). ${ }^{35}$

Por lo anterior resulta claro por qué Aristóteles afirma ${ }^{36}$ que la mayoría de los animales, incluido el hombre, pasa mayor

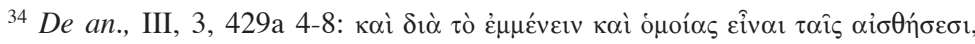

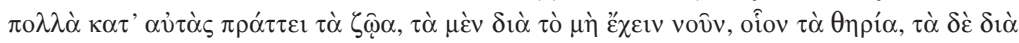

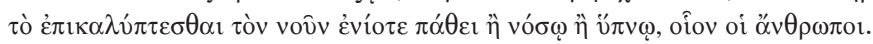

${ }^{35}$ Cf. De insomn., 3, 461b 21-30. Una explicación más detallada acerca de la imagen de semejanza y de cómo se comporta dentro del alma en ausencia del objeto verdadero se encuentra en De mem. et rem., 1, 450b 10-451 a 14: "Por tanto, en unos no permanece la imagen en su alma, pero de los otros, no se toca. No obstante, si tal cosa es lo que ocurre acerca de la memoria ¿acaso esto es lo que recuerda la afección o aquello a partir de lo cual se originó? Si es esto último, en efecto, ninguna de las cosas ausentes podríamos recordar; pero si es aquello ¿cómo es que habiendo percibido esto recordamos aquello que no percibimos: lo ausente? Si es semejante, exactamente como un grabado o una pintura en nosotros ¿por qué razón la sensación de esto mismo sería memoria de otra cosa pero no de esto mismo?

${ }^{36}$ Una afirmación a la que remite este pasaje, si bien no de manera directa, es la que hace en Met., A, 1, 981b 30-982a 1, de que los animales incapaces de es-
} 
tiempo en el engaño y que el alma permanece durante un tiempo más prolongado en el engaño que en la verdad. ${ }^{37}$ Pero, además, para quien siga con cuidado en el texto griego la exposición de Aristóteles acerca de lo verdadero (alēthés), de la causa de lo falso (pseûdos) y del engaño (apátē), saltará a la vista cómo es que, aun sin aludir al parentesco etimológico de las palabras lanthánein y alēthés, en el uso intencionado que simultáneamente hace de ellas y mediante una resonancia de juego de palabras que su explicación produce, pone de manifiesto lo que de hecho sucede en el fenómeno que nos explica. El verbo lanthánō y la forma radical de la que procede, lêthō, significa estar oculto, mantenerse oculto, pasar inadvertido; el adjetivo a-lèthés, por consiguiente, significa por el alfa privativa no oculto, no inadvertido. Así pues - según la explicación que nos da acerca de aquello que produce lo falso y el engaño - durante la vigilia, en el momento en que la percepción está en acto, se produce una imagen que representa dentro del alma la forma del objeto percibido sin la materia; no es la piedra ${ }^{38}$ ni el anillo lo que está dentro del alma cuando el ojo percibe este objeto, sino la forma de la piedra o del anillo sin la materia de que está hecha, sin el bronce y sin el oro; esa imagen, por tanto, no es el objeto externo mismo, sino solamente una semejanza (homoiôtês) del objeto verdadero (tô̂ alêthô̂s). Después de que el objeto verdadero que estaba presente al momento de la percepción se ha ido, es también verdadero decir (alēthés eipeîn) que es tal cual es el objeto verdadero, pero que no es el verdadero. Es decir, que a la parte soberana del alma y que juzga y discierne la imagen del objeto verdadero no se le oculta - (ou lanthánei) pode-

cuchar no aprenden, viven por sus imaginaciones y recuerdos y participan poco

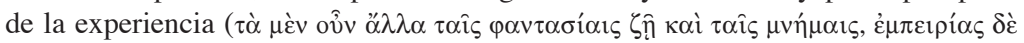
$\mu \varepsilon \tau \dot{\varepsilon} \chi \varepsilon 1 \mu 1 \kappa \rho o ́ v)$.

${ }^{37}$ Cf. De an., III, 3, 427a 29-b 2. Cf. también III, 3, 429a 1.

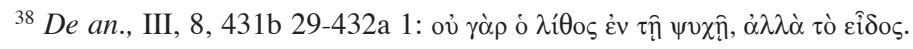


mos parafrasear aquí a Aristóteles - que lo uno es la imagen y lo otro es el objeto verdadero (tò alêthés); literalmente, no se le oculta (ou lanthánei) que lo otro es el objeto que no se oculta (tò a-lèthés) o que no pasa inadvertido (alēthés) o que se de-vela o des-cubre (a-lēthés). Esto se diría en griego: ou lanthánei hoti héteros tò a-lēthés estín. La negación ou antepuesta al verbo lanthánei expresa el mismo significado que el adjetivo a-lèthés, pues el sentido del alfa privativa inicial es equivalente al de una negación. No sin razón, dicho sea de paso, Heidegger advertía que la alêtheia no debía ser traducida como Wahrheit - pues por verdad se entiende la validez de declaraciones en forma de oraciones - sino más bien como Unverborgenheit. En efecto, decía, lo que hay que pensar en la alêtheia no tiene en sentido estricto nada que ver con la verdad (Wahrheit), sino antes bien tiene que ver absolutamente con el no ocultamiento (Unverborgenheit) que supone toda determinación de la verdad. ${ }^{39}$ Así pues, dado que, aun cuando ha cesado el acto de la percepción, esa imagen de semejanza permanece dentro del alma y el órgano sensorial sigue en movimiento por efecto del movimiento que, a su vez, produjo en él el objeto sensible que ya está ausente, la permanencia de las imágenes residuales en el órgano sensorial, su movimiento dentro de éste y la semejanza de las imágenes con las sensaciones, sobre todo durante el dormir, durante la pasión o dentro de la enfermedad hacen que el objeto semejante (tò hómoion), la imagen, parezca ser el objeto verdadero (tò alêthés). ${ }^{40}$ La potencia del dormir, afirma Aristóteles, ${ }^{41}$ es tan grande, que hace que el hecho de que uno toma el

${ }^{39}$ Cf. Heidegger, Seminare, p. 402.

${ }^{40}$ Rhet., I, 1, 1355a 14-18: "Pues es propio de la misma facultad <del alma > el

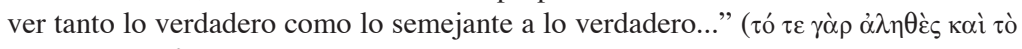

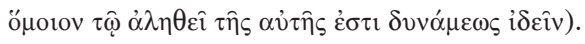

${ }^{41}$ Pero también la potencia de la pasión y de la enfermedad, junto a la del sueño, podríamos añadir aquí. 
objeto semejante por el objeto verdadero (tò alêthés $=$ lo que no se oculta) se oculte (lanthánei). La causa del engaño es, por tanto, la imaginación, pues son las imágenes residuales que quedan después de que el objeto sensible ya no está las que ponen en movimiento a los demás animales que carecen de intelecto, y son las que mueven al hombre durante el reposo, la pasión o la enfermedad a causa de que se le nubla el intelecto (dià tò epikalýptesthai tón noûn).

A esta disposición en la que la imaginación nos engaña, lo mismo durante el sueño que durante la vigilia, parece contribuir sobre todo la pasión (páthos) durante el tiempo en que estamos despiertos, pues nos engañamos más fácilmente con respecto a las sensaciones, dice el Estagirita, cuando estamos sumidos en las pasiones (en tô̂s páthesin). Así sucede, por ejemplo, al cobarde en su miedo o al enamorado en su amor, de modo que a partir de una pequeña semejanza el uno parece ver a los enemigos y el otro al objeto amado, y cuanto más se encuentra dentro de la pasión, tanto más es imaginado el objeto a partir de una pequeña semejanza (ap' elássonos homoiótētos). ${ }^{42}$ Así pues, el engañarse durante la vigilia ocurre sobre todo dentro del estado de afección del alma al que Aristóteles llama páthos, pasión (equivalente al estado de afección que se produce durante el dormir, pues llama también páthos al soñar), ${ }^{43}$ y que no difiere cualitativamente de los estados patológicos en los que, al encontrarnos afectados, nos es imposible discernir la realidad sensible sin incurrir en lo falso. Son pasiones, en efecto, aquellas afecciones del alma a las que les sigue placer y dolor, por cuya causa, siendo alterado con respecto a su percepción del mundo sensible, el sujeto cambia en sus juicios frente a la realidad externa. ${ }^{44}$ Por esa

\footnotetext{
${ }^{42}$ Cf. De insomn., 2, 460b 3-8.

${ }^{43}$ De insomn., 2, 459a 9: "esta afección (tò páthos) a la que llamamos soñar"

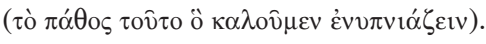

${ }^{44}$ Cf. Rhet., II, 1, 1378a 19.
} 
razón, una y la misma cosa no es imaginada de igual modo por el que ama que por quien odia, por el que se encuentra encolerizado que por quien está libre del apetito de venganza. El estado habitual en el que se encuentra una persona irascible es tal que, por imaginar y concluir de manera anticipada que ella misma es objeto de una ofensa, es llevada a incurrir en el engaño y a realizar cosas que quizá no le convenga hacer y que nadie que estuviese libre de apetito de venganza estaría dispuesto a realizar. Su estado es semejante al de los sirvientes que, por su disposición ardiente para servir, cuando el amo dice "dame", siendo llevados por su ardor, antes de oír lo que convenía dar ya lo dieron, y se equivocaron por completo en la acción; pues convenía dar un libro, y sin embargo lo que dieron fue un estilete. ${ }^{45} \mathrm{Su}$ reacción es parecida a la de los perros que, antes de averiguar si el que toca es un amigo de su amo, tan pronto como escuchan un sonido se precipitan ladrando tras la puerta. ${ }^{46}$

La causa de su disposición hacia la venganza es que el estado habitual en el que se encuentra es doloroso. La ira, en efecto, es un apetito de venganza acompañado de dolor, causado por imaginar un menosprecio hecho a uno mismo o a alguno de sus seres queridos, de parte de algún otro a quien no le concierne hacer tal menosprecio imaginario. ${ }^{47}$ En la definición aristotélica de la ira (orgê) encontramos cinco elementos engarzados que tienen que ver directamente con la imaginación (phantasía): el apetito de venganza, el dolor, el placer y la doble creencia de que hay un menosprecio y de

\footnotetext{
${ }^{45}$ Cf. MM, II, 6, 1202b 12-17. Trad. de J. Araiza, en La Ética magna de Aristóteles: análisis, interpretación y traducción de una obra política, tesis de licenciatura, FCPyS, UNAM, 1997, p. 248.

${ }^{46}$ Cf. EN, VII, 7, 1149a 28.

${ }^{47} \mathrm{El}$ aspecto imaginario que determina la causa de la ira está dado por las palabras dià phainoménēn oligōrían, que pueden ser traducidas literalmente en el contexto como a causa de un menosprecio imaginario. Rhet., II, 2, 1378a 30-31:

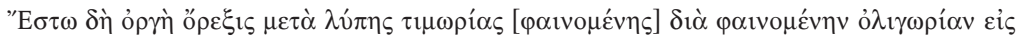
$\alpha \hat{v} \tau \grave{o} v \ddot{\eta}\langle\tau \imath\rangle \tau \hat{\omega} v \alpha \hat{\tau} \tau \mathrm{ov}$.
} 
que dicho menosprecio es inferido por otro a quien no le concierne hacerlo. De hecho, el placer y el dolor parecen ser una especie de componentes esenciales de la imaginación sensitiva. La causa que produce el dolor y que pone en movimiento al doliente es la imaginación del menosprecio; pues tan pronto como se imagina que hay ultraje o menosprecio, concluye que es necesario pelear contra éste de quien se imagina que procede el desprecio, de manera que al punto se molesta y precipita a la venganza. La causa final, aquello con vistas a lo cual se puso en movimiento, es la búsqueda de placer, pues la venganza aparece como una satisfacción y un cumplimiento del apetito doloroso. Y es que la furia es más dulce que la miel que destila gota a gota en el pecho de los hombres. ${ }^{48}$ Así pues, a todo arranque doloroso de ira le sigue una especie de placer que procede de la esperanza de vengarse, en la medida en que resulta placentera la creencia de poder alcanzar aquello que cada uno apetece. Y no es lo mismo, según Aristóteles, el castigo que la venganza, pues el castigo (kólasis) tiene como objeto a aquel que lo padece, mientras que la venganza (timōría) se orienta hacia aquel que la apetece para su satisfacción. ${ }^{49}$ Esto no excluye, sin embargo, que el que busca el castigo del otro no comience precisamente con un castigo hacia sí mismo, pues un castigo es doloroso y la ira es un apetito doloroso en busca de placer. Que quien se encuentra en tal estado es semejante al que se halla dormido y sueña, puede percibirse claramente por lo que dice el Estagirita:

Le sigue, en efecto, tanto por esa razón una especie de placer, como también porque durante un tiempo permanecen ocupados con el pensamiento en vengarse. Por consiguiente, la phantasía

\footnotetext{
${ }^{48}$ Como dice Homero acerca de la furia (thymós), según Aristóteles, Rhet., II,

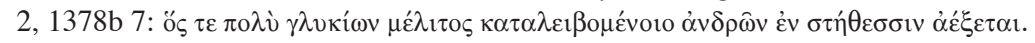
Cf. Il., XVIII, 109 ss.

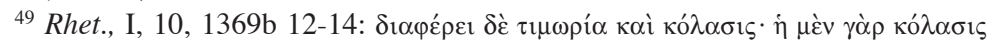

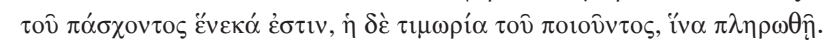


que entonces surge, produce dentro un placer, que es tal como el que tiene lugar en los sueños. ${ }^{50}$

Por lo que se refiere al apetito de lo placentero, a los placeres del alimento, de la bebida y del sexo, el que se encuentra sumido en el deseo (epithymía) y en la esperanza (elpís), en la medida en que ha de ser placentero lo que desea y espera, imagina el objeto como algo que realmente va a ocurrir y como un bien. Le ocurre lo mismo que a los que, sumidos en fiebre, sienten placer por la sed, cuando se acuerdan que bebieron o cuando tienen la esperanza de saciarla. Algo semejante sucede a los enamorados, los cuales tanto al hablar, escribir o hacer cualquier otra cosa acerca del objeto que aman sienten placer, por la creencia de que al recordarlo perciben el objeto amado. ${ }^{51}$ En el deseo (epithymía) lo mismo que en el amor (érōs) se da una mezcla de placer y de dolor tanto en presencia como en ausencia del objeto. En efecto, no sólo al estar presente se alegran, sino también cuando al estar ausente lo recuerdan, y el dolor sobreviene especialmente por no estar presente. Parece, sin embargo, que la función del recuerdo y la imaginación radica precisamente en expulsar el dolor mediante el placer

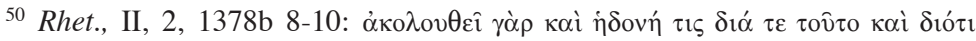

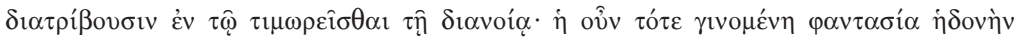

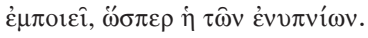

${ }^{51}$ La phantasía, como ha sido dicho, es el movimiento que se produce por la sensación en acto. Cuando el objeto es percibido, a partir del movimiento que se da por el contacto del objeto y del órgano sensorial se origina un movimiento asociativo en el alma, el cual, a su vez, hace que el animal se mueva en una o en otra dirección. El movimiento producido por la percepción sensorial despierta en el animal la asociación de algo placentero o doloroso que lo mueve hacia adelante o hacia atrás. El placer lo mueve a buscar lo que imagina que es bueno y el dolor lo mueve a huir de lo que imagina como malo. Cuando el león escucha un sonido que asocia con el bramido de un buey, siente placer no por percibir la voz del buey, sino por imaginar a partir del bramido del buey que su alimento está cerca. Los perros tampoco sienten placer por el olor de las liebres, sino porque el olfato despierta en ellos y les produce al punto la sensación del alimento. Cf. EN, III, 13, 1118 a 18.
} 
que traen consigo, y que a un dolor excesivo corresponde la búsqueda de un placer excesivo. Esto puede verse también en el caso del duelo, cuando, ante el dolor por la pérdida del objeto amado, el recuerdo trae consigo en el doliente un placer, cuyo límite respecto del dolor no es fácil determinar:

Tanto en las situaciones de luto como en los cantos fúnebres de igual modo sobreviene cierta especie de placer: el dolor se produce, en efecto, por el hecho de que él ya no existe; en cambio, el placer, por tener el recuerdo y por ver en cierto modo lo que él hacía y cómo era. Por eso ha sido dicho también con razón: "Así dijo, y en todos movió el intenso deseo de llorar a gritos". ${ }^{52}$

Podemos advertir, por este pasaje, que la función de la percepción sensorial radica en conocer la a-lêtheia, una verdad o un no-ocultamiento que produce dolor, porque el sujeto percibe y no se le oculta (ou lanthánei vale decir) el hecho de que el objeto amado ya no está presente, ya no existe; y que la función de la phantasía radica en hacer presente lo ausente en cierta forma, en convertir el dolor en placer mediante el recuerdo, pues el recuerdo y el "ver en cierto modo lo que él hacía y cómo era" trae consigo la generación de un placer que se origina en el intenso deseo de llorar a gritos. Al decir "por ver en cierto modo lo que él hacía y cómo era", se refiere Aristóteles al hecho de que el sujeto doliente imagina al ausente como presente; y de ahí resulta claro que esta operación equivalente al engaño por el que la imaginación toma la imagen de semejanza - presente - por el objeto verdadero - ya ausente - es la misma que produce el placer. Se trata en tal caso de un placer que, según la bella y reveladora frase de Homero, sobreviene tras el recuerdo, precisamente con el intenso deseo de llorar a gritos.

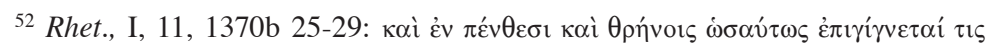

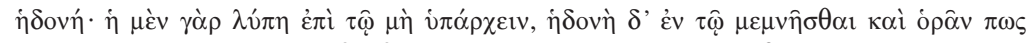

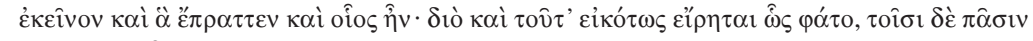

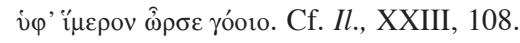


Pero hagamos aquí una breve digresión, para dejar constancia de la claridad con que se expresa Aristóteles al advertir que lo que está en juego en la investigación ética, especialmente en relación con los placeres y dolores del cuerpo, es precisamente la búsqueda de lo verdadero y que en esta búsqueda es importante que no se nos oculte cuál es la causa de lo falso:

Puesto que es conveniente decir no solamente lo verdadero sino también la causa de lo falso - esto, en efecto, contribuye a la convicción, pues cuando se manifiesta fundada la causa de por qué es imaginado como verdadero lo que no es en realidad verdadero, ello produce el que uno crea más en lo verdadero. De manera que hay que decir por qué razón los placeres corporales son imaginados como preferibles. ${ }^{53}$

Es preciso hacer notar que el contexto en el que se encuentra este pasaje tiene como centro el estudio del placer corporal (hêdonê sōmatikêe) y, además, que en las cinco líneas en que justifica por qué conviene que advirtamos la causa del engaño en el que nos hace caer la imaginación, Aristóteles emplea cuatro veces el concepto alêthés, ${ }^{54}$ una vez el concepto de lo falso (tò pseûdos) y tres veces el verbo phaínō en su voz media. Si nos detenemos un poco en el análisis de este verbo, veremos que su significado tiene mucho que ver con el sentido del adjetivo alēthés. En efecto, phaínō - así, en voz activa- quiere decir traer a la luz, hacer visible, hacer aparecer,

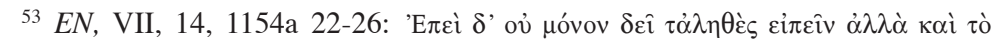

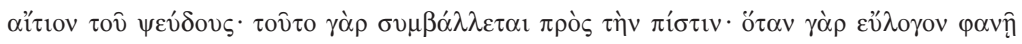

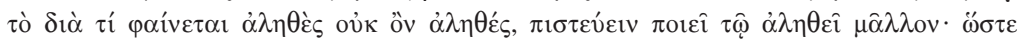

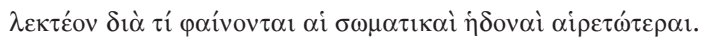

${ }^{54}$ Una de ellas precedida por la negación ouk y el participio del verbo ser on:

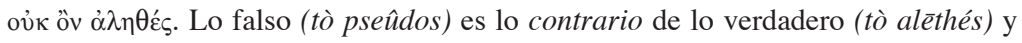
lo que no es verdadero se opone contradictoriamente a lo verdadero. En el contexto de este pasaje, lo no verdadero equivale a lo falso. Ambos se oponen a lo verdadero, pero aquello contradictoriamente, esto último en tanto que contrario. 
descubrir ${ }^{55}$ y en su forma de voz media, phaínomai, significa llegar a ser visible, aparecer, mostrarse, mientras que la palabra a-lêthés (verdadero) quiere decir literalmente lo no-oculto, lo que no se esconde, lo que no deja de mostrarse, lo que se devela o des-cubre. Así pues, tanto en el uso que hace del verbo phaínomai como en el empleo que hace del adjetivo alēthés, Aristóteles juega de nueva cuenta con la noción del hacerse visible, del aparecer, del mostrarse, del no ocultarse, no esconderse, no dejar de mostrarse, de-velarse, des-cubrirse. Todas estas formas son atributos de la alêtheia; pues la a-lêtheia es la que no se oculta (ou lanthanei), en otras palabras, la que se hace visible (phaínetai). Ahora bien, aquí se trata de decir no sólo en qué consiste lo verdadero, sino también cuál es la causa de lo falso; pues nos persuadimos más en relación con la verdad cuando se nos muestra fundada la causa de por qué es imaginado como verdadero algo que no es verdadero.

Por lo que no es verdadero (ouk on alēthés) debemos entender aquí la afirmación de que los placeres corporales son preferibles; pues los placeres del cuerpo no son elegibles, de modo que es falso afirmar que los placeres corporales son preferibles. Lo verdadero es que los placeres preferibles y elegibles por sí mismos son los no corporales. Por placeres corporales debemos entender aquellos a los que precede dolor y que hacen las veces de remedio, como el placer del alimento, de la bebida, del sexo, el placer de la venganza y el que deriva de la ingestión de objetos extraños a la naturaleza del cuerpo o sustancias tóxicas como alcohol y drogas, o alcaloides y medicamentos. Por placeres no corporales debemos entender aquellos a los que no precede dolor alguno y que se disfrutan no como un remedio ${ }^{56}$ o curativo a un dolor, sino por

\footnotetext{
${ }^{55}$ Dr. W. Pape's Griechisch-Deutsches Handwörterbuch zu drei Bänden, Dritte Auflage bearbeitet von M. Sengebusch, fünfter Abdruck, Druck und Verlag von F. Bieweg und Sohn, Braunschweig, 1908, s. 1250-1251.

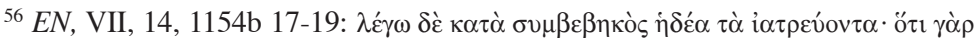

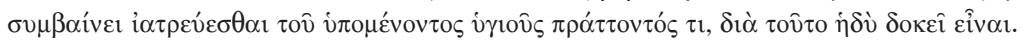


sí mismos; por ejemplo, el placer de pensar, de contemplar, de escuchar; pues estas actividades, a diferencia de aquellos objetos, se buscan y se disfrutan por sí mismas, sin que les preceda ningún dolor. ${ }^{57}$

Así pues, retomando el hilo de nuestro tema, según Aristóteles, la procuración de placer llega a ser como un remedio (iatreía) del dolor, y por esa razón ciertos placeres corporales se manifiestan a la imaginación como placeres preferibles, de manera que, cuanto más excesivos son los dolores percibidos, tanto más violentos son los remedios que se persiguen, en la creencia de que tales placeres curativos son buenos. El engaño consiste en la creencia de que el remedio que produce la curación es bueno. Ahora bien, un remedio no es bueno en sí mismo, sino que lo es por accidente, en la medida en que cura una necesidad. Pues toda curación al igual que toda operación quirúrgica tiene que ver con algo enfermo, de modo que si una curación es buena, ha de serlo nada más para este enfermo en particular. En cambio, lo bueno en un sentido absoluto (haplôs) se dice con respecto a todo lo que está sano. Así pues, lo que es bueno para un enfermo - una operación o una rehabilitación - es dañino para un hombre sano. Además, una peculiaridad de aquellos que, por su naturaleza mórbida - sea congénita o adquirida - , persiguen esa clase de curaciones, consiste en que no pueden disfrutar de otra especie de placeres, de manera que ellos mismos se procuran esta especie de sed.

Aunque es claro para quien ha seguido alguna vez con atención los tratados de Ética de Aristóteles, que, al explicar la

\footnotetext{
${ }^{57}$ Cf. EN, I, 6, 1096b 17. MM, II, 7: "Por tanto, aquí hay dolor, donde hay generación de placer. Sin embargo, en el caso de la visión, de la audición y de la percepción olfativa no hay precedencia de dolor; pues nadie que haya sentido placer por ver o por oler padeció antes dolor. Y de modo semejante también en el caso del pensamiento es posible que el que contempla algo sienta placer sin que haya padecido antes dolor, de manera que habrá una especie de placer que no es generación".
} 
causa del engaño en relación con lo que verdaderamente es placentero y doloroso, tiene en vista y se refiere sobre todo al llamado incontinente (akratês), aquí merece especial mención el caso de la melancolía, una especie de hábito crónico que por su naturaleza parece encontrarse más cerca de la intemperancia (akolasía) que de la incontinencia (akrasía):

Los melancólicos por su naturaleza requieren siempre de un remedio; pues su cuerpo está permanentemente irritado y siempre se encuentran en un apetito violento. Y el placer expulsa tanto el dolor contrario como cualquier otro, si es intenso, y por eso llegan a ser intemperantes y malos. ${ }^{58}$

En este punto conviene retomar la pregunta sobre la verdad práctica: ¿en qué consiste y cómo se analiza la alêtheia praktikê según la teoría de Aristóteles? La cuestión acerca de la verdad práctica se encuentra estrechamente vinculada a la pregunta sobre la causa del movimiento en el ser humano (ánthrōpos). ${ }^{59} \mathrm{La}$ acción (prâxis), en efecto, es una especie de movimiento que se origina dentro del alma como resultado de un proceso deliberativo ${ }^{60}$ y de una elección. Dado que la elección es resultado del proceso deliberativo previo, y deliberar es lo mismo que razonar, ${ }^{61}$ pero un razonamiento supone la palabra (lógos), de ahí se sigue que los demás animales no participan de la acción, en la medida en que tampoco participan de la palabra (lógos). La acción (prâxis) es una clase de estructura psíquica que se compone de una deliberación (boúleusis), la cual tiene a su vez como fin una elección (proaíresis). Y la elección es el principio de la acción, en el sentido de causa de donde procede el principio del movimiento. Así pues,

\footnotetext{
${ }^{58}$ Cf. EN, VII, 14, 1154b 11-15.

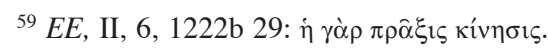

${ }^{60}$ Cf. J. Araiza, “Ética nicomaquea, III: la deliberación”, en Noua tellus, 19-2, IIFL, UNAM, 2001, pp. 57-67.

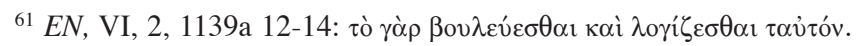


si el hombre, al igual que los demás animales, se mueve por impulso o por tracción, la causa de que él se impulse hacia adelante es la elección. La causa que, a su vez, lo atrae hacia adelante, es lo apetecible (tò orektón) y lo inteligible (tò noētón); pues ningún animal se mueve a no ser que busque algo o huya de algo, y busca lo bello (tò kalón), lo conveniente (tò symphéron) o lo placentero (to hêdy), pero huye de lo vergonzoso (tò aischrón), de lo nocivo (tò blaberón) y lo doloroso (tò lyperón). ${ }^{62}$ Ahora bien, no importa si lo que mueve por tracción al animal es lo bello, lo conveniente o lo placentero o es antes aquello que él imagina que es bello, conveniente o placentero; el que es bueno en cuanto al carácter (ho agathós), dice Aristóteles, es correcto (katorthotikós) con relación a estos objetos; el que es éticamente malo (ho kakós) yerra (hamartētikós). ${ }^{63}$ De ahí se puede entender también que, así como con respecto a la constitución corporal hay hombres sanos - a los que lo dulce sabe dulce y lo amargo, amargoy hombres enfermos - a los que lo dulce sabe amargo y lo amargo dulce - así también en lo concerniente a la disposición anímica hay algunos en los que, a consecuencia del buen estado que guarda su imaginación, las cosas placenteras parecen placenteras y las dolorosas, dolorosas, y algunos en los que, a consecuencia de un trastorno que padece su imaginación, las cosas placenteras parecen dolorosas y las dolorosas placenteras. De esta manera, hay algunos que persiguen lo vergonzoso como algo bello, lo nocivo como algo conveniente y lo doloroso como placentero, y huyen de lo bueno, de lo útil y lo agradable como si fuesen respectivamente algo malo, nocivo y doloroso.

Todo el proceso y el desplazamiento de lugar en el humano se presenta en forma de razonamiento y como un movimien-

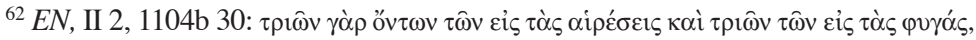

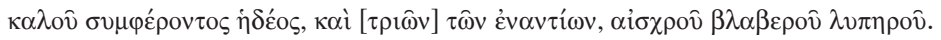

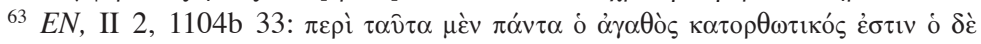

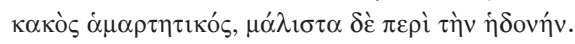


to en el que participan dos facultades del alma: el apetito (órexis) ${ }^{64}$ y el pensamiento (diánoia). Dado que un razonamiento se compone de dos premisas - la una universal, la otra particular - y, además, de una conclusión, la acción es como la conclusión del razonamiento. ${ }^{65}$ Por ejemplo, si hay sed, el deseo (epithymía) dice "debo beber"; ahora bien, "esto es bebible" - dice la percepción sensorial o la phantasía o el intelecto-, de modo que al punto bebe. ${ }^{66}$ La premisa particular es una opinión respecto del objeto sensible: "esto es bebible"; y dicha opinión de que "esto es bebible" es la que da impulso y orientación a la acción concreta de beber. ${ }^{67}$ Lo bebible, asimismo, es lo apetecible, aquello que en tanto causa final mueve sin ser movido. Tal como el objeto amado (tò erômenon) mueve al sujeto amante (ho erastês) y el objeto deseado (tò epithymētón) mueve al sujeto deseante (ho epithymôn) - pues el objeto mueve al sujeto sin moverse-, así lo que parece placentero mueve al hombre sin moverse. Es evidente, por otra parte, que el sujeto amante o deseante no se

\footnotetext{
${ }^{64} \mathrm{El}$ apetito (órexis) es una especie de movimiento en acto. Cf. De an., III, 10,

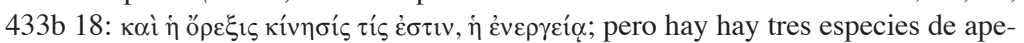
tito: anhelo (bóulesis), furia (thymós) y deseo (epithymía). El anhelo es apetito de lo bello, pues anhelamos cuando creemos que algo es bello; sin embargo, por esta misma razón, es apetito de las cosas convenientes: por ejemplo, si anhelamos estar sanos, anhelaremos también las cosas saludables, aquellas que nos convienen para producir y preservar la salud. El anhelo (bóulesis), por tanto, se refiere a lo bello, a lo bueno y a las cosas convenientes. La furia (thymós) es apetito de venganza y se refiere a los actos vengativos (ta timoretiká); por eso podríamos afirmar que esta especie de apetito es prácticamente lo mismo que la ira (orgué), pues la ira, según nos dice Aristóteles en Rhet., II, 2, 1378a 31, es apetito de venganza (órexis timorías). El deseo (epithymía) es apetito de lo placentero, pues por el deseo se hacen cuantas cosas son imaginadas placenteras.

${ }^{65}$ Cf. MA, 8, 701a 22.

${ }^{66}$ Cf. $M A, 8,701$ a 32. Es así como el animal humano se impulsa a moverse y a actuar; la causa última del movimiento es el apetito (órexis) y éste se produce dentro del hombre o bien a través de la percepción sensorial, o bien a través de la phantasía o mediante la intelección.

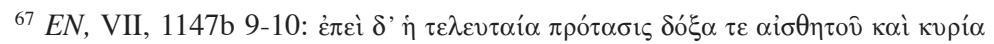
$\tau \hat{\omega} v \pi \rho \alpha ́ \xi \varepsilon \varepsilon \omega$.
} 
mueve excepto si le parece que el objeto es sobre todo placentero; pues si le parece que es bello o que conviene, también le parece placentero. Es decir, se mueve por resultado de una especie de opinión. Por eso afirma Aristóteles que "apetecemos porque nos parece, no nos parece porque apetecemos". ${ }^{68}$ En otras palabras, opinamos porque hemos escuchado o hemos sido persuadidos de que algo es bello o placentero, y por causa de esta convicción apetecemos aquello que nos parece deseable. El deseo, por consiguiente, no se da sin la participación de la opinión; pero, dado que la opinión tampoco se da sin imaginación, de ahí se sigue que todo deseo se acompaña asimismo de imaginación. Es deseable, en efecto, aquello que es imaginado bello. ${ }^{69}$

Ahora bien, el apetito (órexis) y la phantasía pueden ser o correctos o incorrectos; por esa razón lo apetecible siempre mueve, sea en tanto que bien o en tanto que bien imaginario. ${ }^{70}$ Y lo apetecible es imaginado siempre placentero, lo contrario de lo apetecible - lo huible - es imaginado en cambio doloroso; de modo que lo uno se busca y de lo otro se huye. Por tanto, lo que mueve al animal por tracción es o el bien o aquello que se imagina que es un bien, y esto es el bien practicable, y lo practicable es aquello que puede ser de otra forma. ${ }^{71}$ Es aquí en donde puede tener lugar el error (hamartía), lo falso (pseûdos) y el engaño (apátē); pues la opinión y el razonamiento - a diferencia del intelecto, la ciencia y la prudencia - admiten la posibilidad de ser también falsos.

Es claro, por otra parte, que hay dos especies de conocimiento: el universal y el particular, de la misma manera en que un razonamiento se compone de una premisa universal

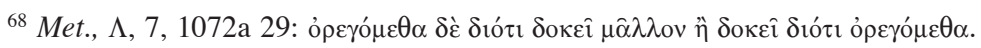

${ }^{69}$ Met., $\Lambda, 7,1072 \mathrm{a} 27$.

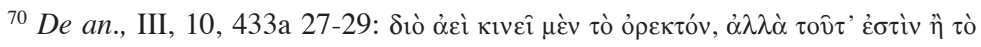
$\alpha \gamma \alpha \theta$ òv ì

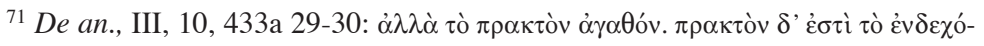

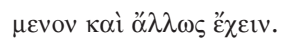


y de otra particular. La premisa particular es una opinión que cae dentro del ámbito de lo particular, donde la percepción sensible es soberana.

Cuando de las dos formas de opinión resulta una sola, entonces el alma debe necesariamente en la dimensión del pensamiento afirmar y decir sí al resultado obtenido; mientras que en la dimensión de los hechos prácticos, donde la opinión se dirige hacia la acción, debe al instante poner en obra el resultado obtenido. Por ejemplo, en el razonamiento práctico: "Todo lo dulce debe gustarse; esto es dulce"; la conclusión llega a ser lo mismo que la acción: "por tanto, esto debe gustarse". Pues necesariamente quien esté en posibilidades de hacerlo y no sea impedido, realizará la conclusión de su razonamiento: disfrutará esto que es imaginado dulce. En este punto conviene señalar que, en conformidad con la teoría de la acción en Aristóteles, se da una relación de analogía entre bondad y verdad, maldad y falsedad: aquello que en el registro del pensamiento práctico (en dianoíai praktikêi) es afirmación y negación, eso mismo en el registro del apetito (en oréxei) es persecución y huída. ${ }^{72}$ La elección es un compuesto de pensamiento (diánoia) y de apetito (órexis), de razón y de impulso irracional; de modo que, si la elección es excelente, es necesario que el pensamiento sea verdadero y el apetito sea correcto. ${ }^{73}$ El apetito persigue los mismos objetos que la razón afirma: el pensamiento práctico y la verdad práctica. ${ }^{74} \mathrm{Si}$, entonces, en conformidad con esto el pensamiento es falso, es necesario que el apetito no sea correcto. Y si el pensamiento no es verdadero o el apetito no es correcto, no es posible que la elección sea excelente. ¿Pero qué significa que la elección sea excelente?

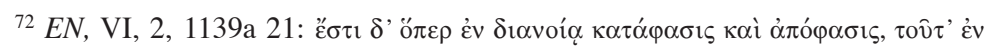

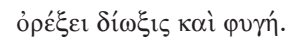

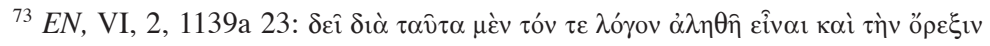
ó $\theta$ ńv.

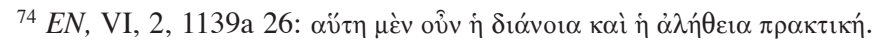


Por elección excelente (proaíresis spoudaía) debemos entender algo semejante a lo que le ocurre al arquero cuando acierta en el blanco. En la esfera de la acción, efectivamente, es posible acertar lo mismo que errar, y sólo se acierta de un modo: cuando se da en el centro; en cambio, se yerra de muchos. Y el acierto es doble: por un lado, se acierta en la dimensión del pensamiento; por otro, en el registro del apetito irracional. Entre lo primero y lo segundo hay una relación de analogía, pues el acierto en el pensamiento es verdadero, mientras que el acierto en el apetito irracional es correcto. La función de la deliberación consiste precisamente en calcular con miras a los hechos prácticos y en ver de qué forma se acierta y se va a alcanzar el objetivo: el que delibera es como el arquero que estira la cuerda y apunta la flecha en la dirección correcta, calculando - según la fuerza de su arco, la distancia y la posición del objeto - dar en el blanco o lo más cerca de él. Que el blanco hacia el cual apuntamos es la felicidad, cómo elabora el alma el trabajo de la deliberación y en qué sentido ese proceso es obra de la prudencia (phrónēsis), ha sido expuesto ya en dos escritos previos. ${ }^{75}$

Así pues, Aristóteles define la elección como intelecto apetitivo o como apetito intelectivo, y afirma que el hombre se encuentra constituido por un principio de esta clase: ${ }^{76}$ es decir, el hombre es un compuesto de alma y cuerpo, es un compuesto de intelecto y de impulso irracional, de razón y de pasio-

\footnotetext{
${ }^{75}$ Cf. J. Araiza, “Ética nicomaquea, III: la deliberación”, en Noua tellus, 19-2, 2001, pp. 57-67; y "La relación entre phrónēsis y sophía, entre bíos politikós y bíos theorétikós en Magna Moralia y en Ethica Nicomachea de Aristóteles", en Noua tellus, 25-2, 2007, pp. 183-207.

${ }^{76} E N$, VI, 2, 1139b 4: "Por eso la elección es o bien intelecto apetitivo o ape-

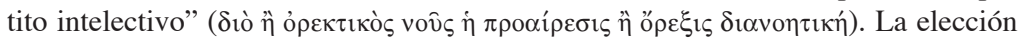
es un apetito deliberativo (órexis bouleutiké), a causa del impulso que nos mueve a actuar, y del pensamiento que le antecede; pues actuamos según la elección, cuando hacemos algo movidos por un impulso para actuar, después de haberlo pensado. Por causa del impulso (hormé) para actuar, la elección es, en efecto, apetito (órexis); pero, por causa del pensamiento (diánoia), es de carácter deliberativo (bouleutiké). Cf. MM, I, 17, 1189a 31 ss.
} 
nes. La elección excelente es posible para el hombre gracias a la posesión de la virtud. En efecto, nadie elige nada, si no es con miras a un fin. Y la elección puede ser excelente o mala; es excelente, cuando el hombre elige a partir de la excelencia o virtud ética. Por otra parte, el fin perfecto es un bien práctico: la felicidad; es aquello con vistas a lo cual todos eligen y hacen todas las cosas. Aquí surge el problema quizá más importante desde el punto de vista práctico del que se ocupan los tratados de ética aristotélicos: ¿Siempre que se da lo verdadero en el orden del pensamiento, se da lo correcto en el registro de los apetitos? ¿O, aun cuando se diera lo verdadero en el pensamiento práctico, podría darse de manera simultánea lo incorrecto en la realización de los apetitos? Éste es el caso del llamado incontinente (akratês), en el que se da un comportamiento absurdo. Pues es akratês quien no se equivoca con el pensamiento sino en el apetito; es aquel que, a pesar de que sabe qué es lo que le conviene hacer y de qué cosas le conviene huir, es movido por su deseo a realizar lo contrario de lo que su razón le ordena, y termina actuando en conformidad con su deseo (epithymía), incluso cuando su pensamiento, siendo verdadero, le indica lo contrario. Por tanto, el incontinente no es prudente, pues prudente es quien no solamente sabe qué es lo que conviene hacer y de qué acciones conviene huir, sino quien es al mismo tiempo consecuente y actúa según ese saber. Pero hemos de volver un poco más adelante a este problema.

Reflexionar, deliberar y razonar con miras a la acción es función de la prudencia. Y no hay prudencia sin virtudes éticas ni virtudes éticas sin prudencia. De ahí que la respuesta a la pregunta cómo se adquiere la verdad práctica — según la perspectiva de la filosofía de Aristóteles - implique necesariamente el recurso de la virtud ética. Por virtud ética (aretê $\bar{e}$ thikê), en Aristóteles no hay que entender en absoluto implicación alguna de ley moral, obligación o deber. Poseer la virtud o excelencia ética en verdad consiste en algo más sencillo de 
lo que comúnmente se cree: no es otra cosa que tener una disposición proporcionada e intermedia, es poseer la mejor disposición habitual del carácter (héxis èthikê), anímica o psíqui$\mathrm{ca}^{77}$ en relación con las pasiones. Por ejemplo, así como la función del ojo es ver, y la virtud del ojo radica en ver bien, pero un ojo enfermo no ve bien; así como la función del pie es caminar, y la virtud del pie reside en caminar bien, pero un pie enfermo no camina bien; así como la función del arquero es tirar al blanco y la excelencia del buen arquero es dar en el blanco; así también la función del hombre consiste en vivir y la excelencia del hombre reside en vivir bien. Ciertamente la función del hombre no se limita a vivir en tanto que animal o en vivir como viviría una planta, sino que consiste en vivir en tanto que hombre. Y la virtud para el hombre reside en vivir bien y en actuar bien. Para decirlo con un par de casos, posee la virtud ética aquel que, al actuar o ponerse en movimiento, no cae en ninguno de los extremos concernientes a la pasión. Ejemplos de pasión tenemos en la ira (orgê), la ambición (pleonexía), el temor (phóbos) y el deseo (epithymía).

En torno a la ira hay una manera intermedia de conducirse, situada entre dos extremos diametralmente opuestos: se encuentra en la mejor disposición habitual quien considera todas las circunstancias particulares de la acción y no se comporta en relación con la ira como el irascible, pues se aíra con quien conviene, como conviene; por lo que conviene, cuando conviene y cuanto conviene. El irascible, en cambio, al igual que el insensible de ira, se engaña con respecto a lo conveniente en cada situación particular. El irascible se aíra con quien no conviene, cuando no conviene, por lo que no conviene, cuanto no conviene o como no conviene; el insensible de ira, a su vez, no se aíra ni siquiera cuando conviene, por lo que conviene, cuanto conviene ni con quien conviene. Es una especie de tarado. El que se ubica hacia el

\footnotetext{
${ }^{77}$ Psychê significa alma.
} 
término medio entre estos dos es el llamado hombre apacible, manso. No es, pues, como el irascible, porque, si se aíra, se aíra con quien conviene, en el momento oportuno y nunca lo hace violentamente ni por un tiempo largo; ni es como el insensible de ira, porque no deja de mostrar su indignación cuando merece la pena.

En relación con el dinero y los bienes económicos hay también una manera intermedia de conducirse y dos extremos: es pródigo (ásōtos) quien gasta en toda ocasión, con quien no conviene, cuanto no conviene y como no conviene; es avaro (aneleútheros), en cambio, el que no gasta ni siquiera cuando conviene ni cuanto conviene ni con quien conviene. En ambos casos el trastorno en relación con su afecto por el dinero parece que tiene que ver de algún modo con el temor a la muerte: el pródigo es aquel que gasta como si fuera a morir en seguida, es aquel que no busca ni siquiera la preservación de sí mismo: á-sōtos, en efecto, significa el que no se salva; el avaro es el que ahorra como si fuera vivir eternamente; es el que se comporta en torno a los bienes económicos y al dinero como un esclavo. El pródigo es el que gasta sin medida no sólo con conocidos y familiares, sino que despilfarra su fortuna aun con extraños y desconocidos y nunca discierne las circunstancias particulares: con quién conviene gastar, cuándo, cuánto, por qué, cómo, para qué, etc.; el avaro es, en cambio, aquel que nunca gasta ni con desconocidos ni con conocidos, y el que no gasta ni siquiera con sus padres, con su esposa o hijos, y, si lo hace, ha de ser un gasto pequeño o lo hace con dolor. Quien se ubica hacia el término medio entre el manirroto y el avaricioso es el llamado liberal (eleuthérios), en otras palabras, el que gasta en la ocasión conveniente, la cantidad conveniente, con la persona que conviene, en la forma en que conviene y por la razón conveniente.

Algo semejante ocurre en relación con el temor y el deseo: es posible temer y desear lo que conviene, cuanto conviene y como conviene o bien equivocarse en cada caso. El que 
acierta en el caso del deseo es templado (sôphrōn) y el que no se equivoca en torno al miedo es el llamado valiente; el temor al que concierne la valentía y sus extremos opuestos se refiere sobre todo a la muerte. Es valiente, pues, el que en relación con la muerte teme en la medida, por la razón y en las circunstancias en que conviene temer. El yerro se da de dos formas: es cobarde el que teme lo no temible (pues a veces es preferible una muerte por una causa bella, antes que sufrir una vida vergozosa), o el que teme el objeto más de lo conveniente o de una manera intensa; es temerario, en cambio, el que no teme en absoluto el objeto ni siquiera cuando conviene temerlo, por ejemplo, para quien tiene una buena disposición en relación con el miedo, es temible una muerte vergonzosa. El templado se encuentra hacia un punto medio entre el intemperante y el insensible respecto de placeres corporales. El intemperante (akólastos) es quien siente placer con lo que no conviene, como no conviene y cuanto no conviene y cree que eso es lo mejor; el insensible es, por el contrario, el que no desea ni siquiera lo que conviene, cuanto, cuando ni como conviene. Dado que se encuentra hacia el medio entre el intemperante y el insensible, el templado es quien ni desea lo que no conviene, ni deja de desear lo que conviene. ${ }^{78} \mathrm{La}$ templanza (sōphrosýnē) es simplemente el mejor hábito que podemos alcanzar en lo que atañe a los placeres corporales. ${ }^{79}$

Nuestra relación con el deseo puede ser correcta o incorrecta, según la clase de deseo, pues hay dos especies: uno natural y otro no natural. El primero es común a todos los hombres y el yerro en tal caso se da solamente por exceso; en cambio, el deseo no natural es aquel que no conviene bajo ningún aspecto ni medida. En efecto, con respecto al deseo se da el yerro de dos maneras y según las dos clases de objeto mencionadas.

\footnotetext{
${ }^{78}$ Cf. EN, III, 15, 1119b 16.

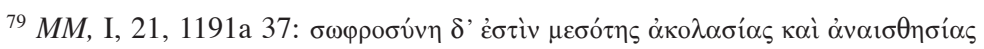

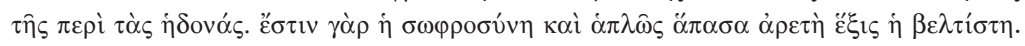


Es común a todos los hombres y natural, por ejemplo, el deseo del alimento, de la bebida y del sexo, pues todos sentimos por naturaleza cierto placer al satisfacerlo (pues, como dice Homero, el joven en el vigor de la edad desea el lecho), ${ }^{80} \mathrm{y}$ el yerro se da en este caso solamente en un sentido: por disfrutarlo más de lo conveniente. Comer, beber y tener relaciones sexuales son actividades no sólo necesarias y naturales, sino también saludables; no obstante, lo mismo la gula, que el alcoholismo y el excesivo sometimiento del cuerpo al contacto sexual dañan evidentemente la salud.

Son deseos adquiridos y particulares, en cambio, aquellos que varían en cada caso particular. Por ejemplo, el deseo de comer tierra, gusanos, o de comer carne humana, el de ultrajar y abusar sexualmente de niños o de cometer homicidio. Las causas son algún tipo de mutilación psíquica, la costumbre o una especie de perversión natural. ${ }^{81}$ A diferencia de los objetos del deseo comunes y naturales, los adquiridos y particulares mueven a yerro en muchos sentidos. Aquellos que los padecen, como es el caso de los incontinentes, desean evidentemente lo que no conviene, y lo saben; y si desean también lo que conviene, lo desean más de lo que conviene o más de lo que los desea la mayoría o como no conviene. Los intemperantes, por su parte, son aquellos que yerran absolutamente en la clase de objeto, pues desean como bueno lo malo y creen que nada hay mejor que gustar lo que les parece placentero. Además, no solamente se equivocan en uno de los aspectos particulares - qué conviene, cuándo, cuánto y cómo conviene - sino en todos a la vez. ${ }^{82}$

Es posible desear, pues, lo conveniente pero de manera no conveniente o también desear lo que no conviene. Si a pesar de que el objeto deseado es conveniente hay engaño, entonces

\footnotetext{
${ }^{80} \mathrm{Cf} . \mathrm{EN}, \mathrm{III}, 13,1118 \mathrm{~b} 10$.

${ }^{81} \mathrm{Cf}$. EN, VII, 5, 1148b 17.

${ }^{82}$ Cf. EN, III, 11, 1118 b 8 ss., y VII, 5, 1148b 15 ss.
} 
el yerro se produce por desearlo como no conviene o cuanto no conviene. El yerro se da en su realización por caer en el exceso. Mas si el objeto que se desea es vergonzoso, entonces el yerro no es por exceso, sino que lo es absolutamente. Por ejemplo, alguien podría desear a la mujer de su amigo y desearla intensamente. Por lo general, en efecto, esta especie de deseos son vehementes. Frente a un deseo de esta especie, el pensamiento (diánoia) podría o ser verdadero o ser falso. Si el pensamiento es verdadero, habría en cuanto al apetito (órexis) dos posibilidades: supongamos que alguien desea seducir a la mujer de su amigo sabiendo que no es correcto su deseo. Su pensamiento intenta disuadirlo de realizar aquello que imagina como dulce, pero su deseo lo impulsa a su cumplimiento. Frente a esta especie de deseo hay una alternativa: o realizarlo o no realizar el deseo. Dado que el intelecto es principio y el pensamiento es verdadero, el sujeto actuante se comporta correctamente, si su acción concuerda con lo que indica su pensamiento. $\mathrm{Si}$, a pesar del apetito de lo placentero que se orienta en una dirección opuesta a la del pensamiento, el cuerpo es movido en la misma dirección que el pensamiento verdadero - en la medida en que el sujeto actúa en conformidad con la razón-, habrá continencia; pero, si el cuerpo es movido por el apetito en sentido contrario a lo que dice el pensamiento, entonces habrá incontinencia; pues, a pesar de que el pensamiento es verdadero, el apetito no es correcto, y se actúa en conformidad con el impulso del apetito irracional. Si el pensamiento, por otra parte, es falso, entonces no cabe la posibilidad de que el apetito sea verdadero. Por ejemplo, si piensa que debe seducir a la mujer de su amigo y que eso es lo mejor, pues toma como punto de partida la premisa de que todo lo que se imagina dulce debe gustarse, entonces el yerro será absoluto, porque el intelecto práctico en él se encuentra totalmente eclipsado.

Éste es un problema crucial del que se ocupa la ética aristotélica y que no debe pasar inadvertido a quien investiga la 
cuestión de la verdad práctica. El fenómeno de la continencia, incontinencia e intemperancia constituye el centro de la cuestión sobre la verdad práctica y la teoría de la acción en Aristóteles. ${ }^{83}$ Aunque estos dos últimos hábitos -incontinencia e intemperancia - tienen por objeto el deseo y los placeres corporales - el deseo en efecto, es apetito de lo placentero, de la bebida, de la comida y del sexo - su estructura es en cierto sentido opuesta y sus modos de ser contrarios.

Al leer en Aristóteles la distinción entre deseos malos y deseos buenos, alguien podría oponer la objeción de que al Estagirita le pasó inadvertido el hecho de que los deseos son relativos y que, por tanto, no pueden ser malos o buenos por sí mismos. De la dificultad de si lo bueno y lo malo es relativo o no lo es, nos ocuparemos en otro lugar. Baste por el momento con señalar que este problema no pasa inadvertido a la filosofía de Aristóteles, en los fenómenos anímicos sucede algo análogo a lo que ocurre en los fenomenos corporales. ${ }^{84}$ Además, si el bien fuese algo relativo, entonces ocurrirían los absurdos en los que cae la tesis de Protágoras, según la cual la medida de todas las cosas es el hombre. En tal caso, dice Aristóteles, la misma cosa sería al mismo tiempo verdadera y falsa ${ }^{85}$ Así pues, en el ámbito de la ética tendríamos que admitir el absurdo de que el deseo de matar a otro hombre, de robar, de comer carne humana o de tener un encuentro sexual con la mujer del amigo es bueno y es malo según le parezca a cada uno y que no es malo per se. Tampoco al médico le sería lícito hablar de enfermedad o salud en el caso de un cuerpo enfermo o de uno sano, pues ambas cosas, enfermedad y salud, serían análogamente relativas. Pero de este problema, de cómo aborda la filosofía peripatética el

\footnotetext{
${ }^{83}$ Su teoría acerca de estos tres hábitos se encuentra expuesta y desarrollada sobre todo en dos de las tres éticas que nos han sido conservadas: $E N$, VII, y $M M$, II, 6.

${ }^{84} \mathrm{Cf}$. nota 43.

${ }^{85}$ Cf. Arist., Met., V, 5, 1009a 6; IX, 3, 1047a 6, y X, 1, 1053a 35.
} 
fenómeno de la incontinencia y de la causa del trastorno en la phantasía humana ha de hablarse en otro lugar. ${ }^{86}$

El incontinente (akratês) es aquel que sabe qué cosas son malas; pero, movido por el placer, las hace aun en contra de su razón, de manera que siente culpa y arrepentimiento después de haberlas realizado. El intemperante (akólastos) es aquel que considera que las cosas malas son buenas, de modo que las realiza sin sentir el menor remordimiento. Éste no se castiga (a-kólastos quiere decir literalmente, por el alfa privativa inicial, el que es incapaz de castigarse. Kólasis, en efecto, significa castigo). El primero, en cambio, carece del poder (a-kratês) de contenerse ante sus deseos. El intemperante (akólastos) es aquel que parte de la premisa universal de que todo lo dulce debe gustarse, de manera que, siempre que esté en posibilidades de hacerlo y si nada se lo impide, gustará aquello que, según su sensación, su phantasía o su intelecto, es dulce. El incontinente parte de la premisa de que no todo lo dulce debe gustarse. En efecto, hay cosas que su intelecto práctico le indica que son malas, de modo que no se engaña en cuanto a la naturaleza del objeto. No obstante, su deseo le dice que son placenteras. Su deseo, por tanto, lo mueve a disfrutarlas aun en contra de su razón. En ambos casos hay un engaño, pero el trastorno que padecen no corresponde a la misma parte del alma: el intemperante tiene eclipsada su razón y no puede discernir lo bueno de lo malo; el incontinente, en cambio, tiene su razón en orden y sabe por su razón qué cosas conviene hacer y qué cosas evitar. El engaño en el incontinente se da en la parte irracional del alma, la phantasía de su parte irracional tiene un trastorno por el cual lo placentero le parece doloroso y lo doloroso placentero. El engaño en el intemperante se da tanto en la parte racional como en la parte irracional del alma; la phantasía no sólo de la parte irracional sino también la de la parte racional del alma se encuentra destruida. Este

\footnotetext{
${ }^{86}$ Cf. EN, VII.
} 
último, por consiguiente, declara en relación con lo placentero y lo doloroso una afirmación falsa y su deseo persigue como si fuesen correctos los objetos que su razón le indica como verdaderos. Así pues, el trastorno se da no solamente en el orden de la phantasía sensitiva, sino también en su phantasía deliberativa. El engaño en él es completo. No importa qué cosa sea aquello que el deseo le indique como placentero. Sea comer carne humana, cometer homicidio, parricidio, filicidio, pederastia, tortura, robo, secuestro, etc., todo esto ha de gustarlo o ha de deliberar cómo y qué hacer para gustarlo. El incontinente, por su parte, hace una afirmación verdadera en relación con lo placentero: "No todo lo dulce debe gustarse". En él no se da el engaño en el registro del pensamiento; pues sabe, por ejemplo, que no conviene seducir ni disfrutar a la mujer ajena, ni que todo lo que el deseo imagine como placentero debe gustarse.

El deseo podría decir, en efecto, que lo más dulce de todo es comerse a un niño o tener una relación sexual extraña - como ocurría a Fálaris, tirano de Agrigento, quien por lo demás se jactaba de su poder de dominio sobre tales apetitos $-{ }^{87}$ y la razón en el incontinente podría simultáneamente prohibir el disfrute del deseo por considerarlo inconveniente o vergonzoso. No obstante, la fuerza del deseo es en él tan intensa y él mismo tan débil, que carece de poder (es un a-kratês) para contenerse y oponerse a su deseo. Al contrario del continente, el cual, pese al deseo vehemente de un objeto vergonzoso, puede controlar su deseo, el incontinente es arrastrado por el apetito de lo placentero. Qué se da en la estructura anímica del incon-

\footnotetext{
${ }^{87} E N$, VII, 5, 1149a 11 ss.: "Los que <padecen un trastorno> por causa de una enfermedad, como la epilepsia o la locura, son mórbidos. Es posible a veces poseer no solamente alguna de estas afecciones y no ser dominado por ellas, me refiero por ejemplo al caso de Fálaris, si <es que es verdad que> se dominaba al sentir el deseo de comerse un niño o frente a un placer absurdo de relaciones sexuales" (oi

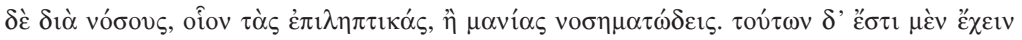

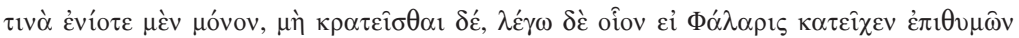

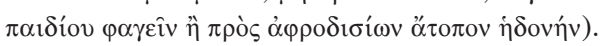


tinente este fenómeno, a qué se debe el trastorno en su imaginación sensitiva y mediante qué tratamiento sería posible curar su padecimiento, es asunto del que habremos de ocuparnos en otra investigación. Los placeres difieren con frecuencia de un sujeto a otro, en la medida en que las mismas cosas producen a unos placer y a otros dolor, las mismas cosas producen a unos dolor y odio y a otros placer y sentimiento afectuoso; las cosas dulces no parecen lo mismo al que tiene fiebre y al que está sano ni lo caliente parece lo mismo al sano que a quien está débil. No obstante, en todos los casos que tienen que ver con los objetos sensibles, lo que el hombre excelente imagina verdadero eso es lo verdadero, y lo que le parece placentero, eso es lo placentero, de modo que aquel que en cuanto a su carácter es bueno, ése mismo es la medida de cada cosa y son placeres verdaderos los que así le parecen y cosas placenteras aquellas en las que se complace. ${ }^{88}$

Y si alguien dijera que todos tienden hacia un bien imaginario (phainoménou agathoû), pero que no son soberanos de su imaginación (phantasía), sino que tal cual cada uno es, tal imagina él también el fin. Así pues, si cada uno es en cierto modo causante de su propia disposición habitual, también será en cierto modo causante de su propia imaginación. De lo contrario, nadie será causante del mal que él mismo hace, sino que lo realiza por ignorancia del fin... ${ }^{89}$

Por todo lo anterior, y dado que la imaginación parece ser la responsable del engaño al actuar y al moverse de lugar, es de absoluta importancia para el hombre el cuidado desde la infancia de las costumbres y de su carácter. ${ }^{90}$ Las costumbres, la

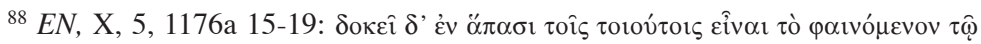

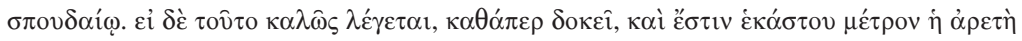

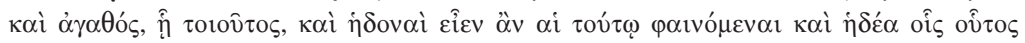

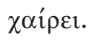

${ }^{89} \mathrm{Cf} . \mathrm{EN}$, III, 5, 1114a 31 ss.

${ }^{90}$ De ahí que según $M M$ deba considerarse la parte pasional o afectiva del alma como punto de partida, antes que la razón, pues al menos en el caso del inconti- 
parte irracional del alma y el cuerpo se generan en el animal antes de que se generen la razón y el intelecto. No obstante, según la doctrina ética de Aristóteles, tanto la razón como el intelecto son para nosotros el fin de nuestra naturaleza, y con vistas a ellos deben organizarse tanto la generación como el cuidado de las costumbres. ${ }^{91}$ Ya desde el nacimiento de las costumbres y del cuidado que ha de tenerse en la formación del carácter, debe consagrarse la educación al servicio del intelecto y del alma, esto es obra de la prudencia y de la política. Por eso, en primer lugar - dice Aristóteles-, es necesario que el cuidado del cuerpo preceda al del alma, y se dé luego el cuidado del apetito (órexis). Pero que el cuidado del apetito sea con vistas al intelecto y el cuidado del cuerpo con vistas al alma. ${ }^{92}$

De aquí resulta evidente por qué la ética en un sentido cronológico precede a la política y por qué la filosofía práctica

nente parecería que la razón adentro no posee en absoluto autoridad. Y la causa es la disposición y el desorden en el que se encuentran las pasiones: "Sin embargo, simplemente la razón no es principio ni conductor de la virtud, como creen los demás, sino más bien son las pasiones. Pues conviene que se engendre en primer lugar cierto impulso irracional hacia lo bello (lo cual también se produce); luego, de esta manera, que la razón emita posteriormente sus decretos y juzgue. Y uno podría ver esto en los niñitos y en los vivientes privados de razón; pues en éstos se engendran antes, desprovistos de razón, impulsos pasionales hacia lo bello, y sobreviniendo después la razón y estando en consonancia, produce la realización de las cosas bellas. Sin embargo, si para las cosas bellas uno toma el principio a partir de la razón, las pasiones no le acompañan dando su consentimiento, antes bien muchas veces le contrarían - Aristóteles se refiere aquí al caso de los incontinentes-; por eso la pasión, que yace en buen estado, parece un principio para la virtud, más que la razón" (MM, II, 7, 1206b 17). A este respecto son muy pertinentes las palabras de Aspasio, filósofo peripatético de la primera mitad del siglo II de nuestra era, quien da testimonio de la importancia que daban a la ética - esto es, al cuidado de las pasiones, de las costumbres y del carácter- las escuelas en la antigüedad (cf. Aspasius, In Arist. Ethica Nicomachea commentaria, 2.9).

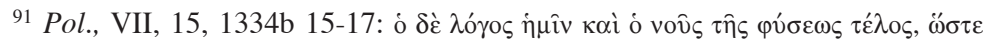

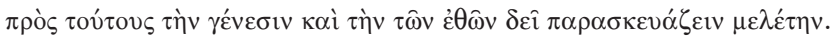

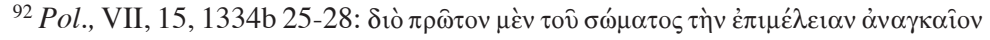

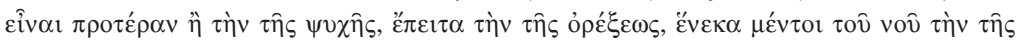

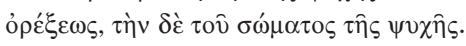


(i. e., la combinación ética y política) es anterior, a su vez, a la filosofía contemplativa. La ética, en efecto, es una especie de arte - análogo a la medicina - que se consagra al cuidado de sí mismo, especialmente al cuidado de la parte irracional del alma del sujeto: del deseo, del temor, la ira, la ambición y las demás pasiones; el político que ha de consagrarse al cuidado de la comunidad política, si ha de ser considerado político en el sentido verdadero del término, ${ }^{93}$ tendría que haber transitado por un proceso de investigación y transformación de sí mismo, de tal modo que sus movimientos y acciones, en su relación con los demás, no sean determinados por sus fantasías, apetitos y pasiones, pues la capacidad de gobernar sobre los otros es una facultad que comienza precisamente en la capacidad de gobernarse a sí mismo. Por lo demás, alguien que no es capaz de ejercer autoridad sobre sus pasiones no puede alcanzar ni procurar a su intelecto las condiciones óptimas para que éste lleve a cabo la actividad que le es propia. Quizá no haya un rasgo más distintivo en la filosofía antigua que la diferencie tanto de la filosofía moderna y contemporánea, como el hecho de que prácticamente en todas las escuelas filosóficas se da la preocupación primeramente por el cuidado del carácter y de las costumbres del filósofo en formación, mientras que es posterior en el tiempo su preocupación por el estudio de la filosofía de la naturaleza (physikê) y de la filosofía contemplativa (theōretikê). Un claro testimonio de ello lo encontramos en las palabras de Aspasio, el más antiguo comentador de Aristóteles, cuando dice:

Así pues, que la sabiduría posee un rango más honorable que la política, podría uno considerarlo a partir de estas y tales cosas. La

${ }^{93}$ Cf. EE, I, 5, 1216a 23-27: "Pero la mayoría de los políticos no alcanzan verdaderamente (alêthôs) el nombre; pues no son políticos según la verdad (katà tēn alêtheian); el político, en efecto, es el que elige las acciones bellas por causa de ellas mismas; en cambio, la mayoría se apega a una vida así con vistas a los bienes económicos y a su ambición". 
ética, como se ha dicho previamente, es la más necesaria. Conviene incluso que nos ocupemos en primer lugar de ella tanto de palabra como de obra, tal como Sócrates juzgaba, no porque uno desprecie el conocimiento de las cosas divinas, ni porque descuide la ciencia de las cosas que conciernen a la naturaleza, cual si fuese superflua, sino por considerar necesario el cuidado del carácter (tên toû êthous epiméleian). También los pitagóricos educaban en primer lugar a sus discípulos tanto en carácter como en razonamientos. Ahora bien, Aristóteles parece estimar en grado sumo esta enseñanza (sc. la ética); y dice que ella se refiere a lo humano. ${ }^{94}$

En efecto, un filósofo, tal como lo concibe el Estagirita, no es quien se refugia en las palabras y cree que, aunque no ponga en práctica su conocimiento acerca de las cosas justas y templadas, sólo por reflexionar y por hablar bien de ellas ya es excelente en cuanto a su carácter:

$<$ Los que así proceden $>$ hacen algo semejante a lo que los enfermos que escuchan cuidadosamente a los médicos, pero no realizan ninguna de sus prescripciones. Así pues, tal como éstos no tendrán su cuerpo en buen estado al cuidarlo de este modo, así tampoco aquéllos tendrán en buen estado su alma, al filosofar de esta manera. ${ }^{95}$

La verdad práctica tiene que ver con el carácter (tò êthos), los hábitos (hai héxeis) y las costumbres (tà éthē) del filósofo. Para decirlo en pocas palabras, no puede ser llamado filósofo - porque no lo es - aquel que no se ha ocupado con esmero del cuidado de sus pasiones, de sus deseos, temores y apetitos. El incontinente, por lo tanto, ni es un oyente apropiado para la enseñanza ética, ${ }^{96}$ ni es filósofo práctico ${ }^{97}$ ni contem-

\footnotetext{
${ }^{94}$ Cf. Aspasius, In Arist. Ethica Nicomachea commentaria, 2.9. Cf. EN, X, 10, $1181 \mathrm{~b} 15$.

${ }^{95} \mathrm{Cf} . E N$, II, 3, 1105b 12.

${ }^{96}$ Cf. EN, I, 2, 1095a 2.

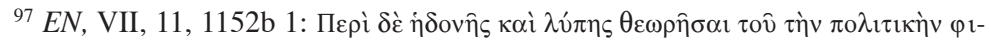

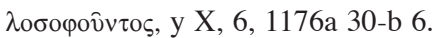


plativo. No es apto para escuchar razonamientos acerca de las acciones de la vida, pues un incontinente vive de conformidad con sus pasiones; por la misma razón no es un filósofo práctico, pues el fin de esta filosofía es la acción, y la acción es lo contrario de la pasión; y tampoco es contemplativo porque la actividad del intelecto y la vida contemplativa se dan sólo en la medida en que el alma se encuentra bien dispuesta para ese fin, es decir, cuando ella está en una disposición de ocio (scholê), libre del jaloneo de las pasiones, en templanza, en valentía, en mansedumbre, en liberalidad y en las demás disposiciones medias que resultan del trabajo de la prudencia (phrónēsis).

La verdad práctica no ha de buscarse, pues, fuera sino dentro del alma del filósofo. La armonía entre el decir y el hacer, entre el dicho y el hecho es una concordancia que se da en relación con sus palabras y acciones. ${ }^{98}$ Aristóteles llama a dicha armonía alêtheia, verdad, y aletheutikós, verdadero, a aquel que vive de conformidad con esta concordancia. La excelencia del carácter que - junto con la amistad (philía) — se alcanza gracias al trabajo de la prudencia se llama alêtheia. Y tanto ésta como la amistad ${ }^{99}$ son modos de ser perfectos, porque se extienden a todos los campos de la vida humana y comprenden dentro de ellas todas las demás excelencias del carácter.

Según Aristóteles, la verdad es un término medio entre la jactancia y la disimulación. Se ubica hacia el término medio aquel que llama cada cosa por su nombre (authékastos), aquel que es verdadero (alētheutikós) tanto en obra como en palabra y reconoce simplemente lo que existe en él, ni más ni menos. ${ }^{100}$ Es un término medio (mésos), porque es posible ser falso de dos maneras: en relación con las cosas que uno

\footnotetext{
${ }^{98}$ Cf. EN, II, 7, 1108a 11, y IV, 13, 1127a 20, b 2.

${ }^{99}$ Cf. J. Araiza, "Sobre la amistad según la teoría ética de Aristóteles", en Nova tellus, 23-2, 2005, pp. 125-159.

${ }^{100}$ Cf. EN, IV, 13, 1127a 23 ss.
} 
sabe y con las cosas que existen en uno mismo. Si se atribuye más cualidades de las que en realidad tiene, o dice saber más de lo que sabe es jactancioso; si, por el contrario, se atribuye a sí mismo menos cualidades de las que posee y finge que sabe menos de lo que en realidad sabe, es disimulado. ${ }^{101}$ Ser verdadero o falso en este sentido no quiere decir serlo en los contratos ni en torno a la justicia o injusticia - pues en tal caso se le llamaría justo o injusto - sino que es verdadero, según Aristóteles, aquel que, sin que esté en juego contrato o cosa justa alguna, dice la verdad en palabra y obra por ser él en su disposición habitual y en su carácter tal como de hecho es. Por tanto, es equitativo y amigo de la verdad (philalêthēs); $\mathrm{y}$ es el que dice la verdad tanto si da lo mismo decirla como si no, pero la dirá aún más cuando no da lo mismo. Es jactancioso (alazôn) el que, por el contrario, sin mayor finalidad finge tener más cualidades de las que en realidad tiene; y es de naturaleza vil, pues de otra forma no se complacería en lo falso. Sin embargo, parece más vanidoso que malintencionado. Es posible que simule para adquirir fama u honra y en tal caso no sería tan censurable, pero si lo hace por dinero y para sacar provecho económico, es más vergonzoso. El jactancioso puede ser como el mentiroso (pseústēs) que simplemente se complace en la mentira, pero también puede pretender la fama o el lucro. En cualquier caso es jactancioso por elección. Si finge porque pretende fama, busca un elogio o una felicitación; pero si lo hace por lucro, finge que sabe cosas que son de provecho para el prójimo, cosas cuya carencia le es posible ocultar (dialatheîn), como ser adivino, sabio o médico (hô̂on mántin, sophón, iatrón). El disimulado (eírōn), al contrario del jactancioso, da en cuanto a su carácter una mejor impresión. No parece hablar con vistas al lucro, sino por huir de tanta ostentación, de modo que niega lo que es tenido por valioso y prestigioso.

${ }^{101}$ Cf. $M M$, I, 32, 1193a 28-38. Cf. EE, III, 7, 1233b 38-1234a 3. 
Así pues, la verdad práctica en Aristóteles tiene que ver con el carácter y el modo de ser del sujeto. En efecto, en la medida en que se define como verdadero aquel que dice tener lo que tiene y dice saber lo que sabe, no por otra razón sino por tener un carácter tal que privilegia la verdad antes que la falsedad, en esa medida la verdad tiene que ver con la ética. Y parece, como puede inferirse por lo que ha sido dicho hasta aquí, que, al menos según la teoría de Aristóteles, el camino para alcanzar la verdad práctica y evitar el engaño es el mismo que conduce a la adquisición del término medio en todas las esferas de la vida del hombre: en relación con el deseo, con el miedo, con el dinero, con la ira, con la ambición y con el resto de los apetitos irracionales. Y tal es el fin de la ética aristotélica: la consecución del término medio. Por lo demás, en cuanto a la pregunta de si es asequible o no el término medio para nosotros, hombres del siglo XXI, de si lo es cómo sería, y si no lo es por qué no lo sería, todo ello ha de ser objeto de una investigación posterior. 